\title{
Scale Formation in Deluged Dry Cooling Systems
}

D. R. Pratt

May 1976

Prepared for the Energy Research and Development Administration under Contract E(45-1):1830 
NOTICE

This report was prepared as an account of work sponsored by the United States Government. Neither the United States nor the Energy Research and Development Administration, nor any of their employees, nor any of their contractors, subcontractors, or their employees, makes any warranty, express or implied, or assumes any legal liability or responsibility for the accuracy, completeness or usefulness of any imformation, apparatus, product or process disclosed, or represents that its use would not infringe privately owned rights.

\author{
PACIFIC NORTHWEST LABORATORY \\ operated by \\ BATTELLE \\ for the
}

ENERGY RESEARCH AND DEVELOPMENT ADMINISTRATION

Under Contract E(45-1)-1830

Printed in the United States of America

Available from

National Technical Information Service

U.S. Department of Commerce

5235 Pont Royal Road

Springfield, Virginia 22151

Frice: Printed Copy \$5.00; Microfiche \$2.25 
BNWL -2060

33679000624926

UC -12

SCALE FORMATION IN DELUGED DRY COOLING SYSTEMS

by

David R. Pratt

May 1976

BATTELLE

Pacific Northwest Laboratories

Richland, Washington 99352 


\section{CONTENTS}

LIST OF FIGURES . . . . . . . . . . . . . . . . . . . . . i i

LIST OF TABLES . . . . . . . . . . . . . . . . . . . . . . iii

1.0 INTRODUCTION . . . . . . . . . . . . . . . . . . . . 1

2.0 THE IMPORTANCE OF CALCIUM CARBONATE SCALE PREVENTION . . . . . . 3

3.0 THEORY OF CALCIUM CARBONATE SCALE FORMATION . . . . . . . . . . . . 5

3.1 Scaling Indexes .................... 5

3.2 Critical pH for Scale Formation . . . . . . . . . . . 10

3.3 Effect of Magnesium and Sulfate Ions on Calcium

Carbonate Solubility ............... 13

4.0 APPLICABILITY OF SCALING THEORY TO DELUGED DCT SYSTEMS . . . . . . 15

4.1 "Pure" Delugate Makeup ................ . 15

4.2 Other Makeup Water Qualities . . . . . . . . . . . . 21

5.0 SCALE FORMED BY DELUGATE EVAPORATION . . . . . . . . . . . . . . 21

6.0 DELUGATE TREATMENT FOR SCALE PREVENTION . . . . . . . . . . . . 23

6.1 Side-Stream Treatment ................ 23

$6.2 \mathrm{pH}$ Control . . . . . . . . . . . . . . . . . . 23

6.2.1 Calcium Sulfate Scale Formation . . . . . . . . 27

7.0 RESEARCH NEEDS . . . . . . . . . . . . . . . . . . 28

8.0 SUMMARY AND CONCLUSIONS . . . . . . . . . . . . . . . . 30

REFERENCES ............................ 33

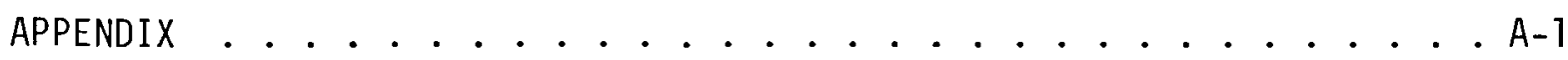




\section{LIST OF FIGURES}

No. Title Page

1. Langelier Saturation Index Chart . . . . . . . . . . . 9

2. Calcium Carbonate Solubility Diagram ........... . 11

3. Scaling Predictions of Various Indexes . . . . . . . . 12

4. Relation Between the Solubility Product Enhancement Factor E, and the Equilibrium Ratio $r_{\mathrm{Mg}}=\left[\mathrm{Mg}^{2+}\right] /\left[\mathrm{Ca}^{2+}\right] . . . . . . .14$

5. Magnesium and Sulfate Ion Effects On The Critical Scaling Constant, $\mathrm{K}_{\mathrm{pHc}}$. . . . . . . . . . . . . . . . . . 15

6. Aqueous Carbonate Equilibrium and Solubility of Calcium Carbonate as a Function of $\mathrm{pH}$ in a System Open to the Atmosphere; Ionic Strength $=0.035$, Temperature $=40^{\circ} \mathrm{C} . . .17$

7. Treatment of Delugate Water to Prevent Formation of Calcium Carbonate Scale ............... 24

8. System for Automatic Control of Delugate pH . . . . . . . 26

9. Acid Delivery, Storage and Transfer System . . . . . . . . 27 


\section{$\underline{\text { LIST OF TABLES }}$}

No. Title $\quad$ Page

1. Reduction in Heat Transfer Coefficient Resulting from Calcium Carbonate Scale in Deluged DCT Systems . . . . . . . 5

2. Equilibrium Values of the Solubility Constant of $\mathrm{CO}_{2}\left(\mathrm{~K}_{H}\right)$, the Dissociation Constants of Carbonic Acid $\left(K_{1}\right.$ and $\left.K_{2}\right)$ and the Solubility Product of Calcium Carbonate $\left(k_{s}\right)$ as They Vary with Temperature ................ 7

3. Ionic Strength Corrections of the Ionization Constants of Carbonic Acid and the Solubility Product of Calcium Carbonate . 8

4. Experimental Values of the Critical $\mathrm{pH}, \mathrm{pH}_{\mathrm{C}}$, and the Critical Scaling Constant, $\mathrm{K}_{\mathrm{pHc}}$, for $\mathrm{CaCO}_{3} \ldots \ldots . . . . . .13$

5. "Pure" Water Quality ................ 16

6. The Equilibrium Distribution of Solutes in Delugate Water Open to the Atmosphere, Ionic Strength $=0.035$, Temperature $=40^{\circ} \mathrm{C} .19$

7. Use of Various Waters as Delugate as a Function of Water Quality 21

8. Approximate Chemical Dosage Rates and Treatment Stream Flow Rates as a Function of Makeup Water Quality ......... 25

9. Approximate Costs of Side-Stream and Makeup Water Treatment . . 26

10. Buildup of Sulfate Concentration in the Delugate as a Function of Makeup Water Quality . . . . . . . . . . . 28 


\subsection{INTRODUCTION}

In the dry cooling concepts under study at Battelle, Pacific Northwest Laboratory, (PNL), waste heat from the power plant condenser is transferred from the intermediate heat transfer fluid to the air by means of an aircooled heat exchanger (dry tower) utilizing finned tubes. Both water and ammonia are being studied as potential intermediate heat transfer fluids; the feasibility of the use of bare plastic tubes instead of metal finned tubes in the dry tower is also being examined.

During the cocler portions of the year, the cooling tower will operate as a completely dry system. During warm periods, however, preliminary studies at PNL and elsewhere ${ }^{(1,2)}$ indicate that deluging portions of the heat exchanger surfaces with water will increase heat rejection capability and significantly reduce the cost of dry cooling. In the deluged dry cooling mode, sensible heating of the air is augmented by heat transfer to the air by evaporation of the deluge water (delugate).

One of the principal uncertainties in the deluge concept is the tendency toward deposition of solids (scaling) from the delugate. Scaling can occur by a) exceeding the solubility limit under continuous flow conditions and b) evaporation of the delugate on the heat exchange surfaces in multiple wet-to-dry cycles. Workers in the USSR studying the concept state that scaling can be avoided by the use of proper water treatment, but the extent of this treatment is not clear. (2) Experience in this country has shown that smooth tubes continuously flooded by a massive flow of water will not develop encrustations provided the water 
is properiy treated and the surface temperature does not exceed about $66^{\circ} \mathrm{C}\left(150^{\circ} \mathrm{F}\right) .^{(3)}$ Again, however, details concerning proper water treatment are not clear.

On the other hand, a veridor of air-cooled heat exchangers in this country has stated that intentional wetting of extended surfaces in U.S. process plants has been unsuccessful. According to this source, water solids and air-borne dirt create serious fin-side fouling problems which affect both heat transfer and mass air flow. (4) This adverse experience has largely been with systems in which water is sprayed on the finned tubes and allowed to completely evaporate; in this case, solids are deposited rapidly in proportion to their concentration in the water and particulate material in the air. (5)

Thus the question of delugate water quality is of major importance in evaluating scale formation and its effect on heat transfer in the deluged dry cooling system. Indeed, scaling (fouling) has been described as the major unresolved problem in heat transfer. ${ }^{(6)}$ This paper will discuss, in relation to the deluged dry cooling system, the importance of scale prevention, the theory of scale formation and application of this theory to the deluged system, the problems of delugate evaporation, and delugate treatment required to prevent scaling. 


\subsection{THE IMPORTANCE OF CALCIUM CARBONATE SCALE PREVENTION}

The importance of preventing the formation of calcium carbonate scale in deluged dry cooling systems can be seen by examining the basic heat transfer equation for heat flow under pure conduction conditions. The heat flow is controlled by three factors:

- the nature of the conducting surface

- the difference in temperature

"the cross secticnal area of the conducting surface.

The heat flow is calculated from the equation: (7)

$$
\eta=U \times \Lambda \times \Delta T
$$

where

$$
\begin{aligned}
Q & =\text { Total heat flow }(B t u / h r), \\
A & =\text { Area of heat transfer surface }\left(\mathrm{ft}^{2}\right), \\
\Delta T & =\text { Temperature difference between the two surfaces }\left({ }^{\circ} \mathrm{F}\right), \\
U & =\text { Heat transfer coefficient }\left(\mathrm{Btu} / \mathrm{hr}-\mathrm{ft} \mathrm{t}^{2}-{ }^{\circ} \mathrm{F}\right) .
\end{aligned}
$$

The overall heat transfer coefficient is given by: (7)

$$
\frac{1}{U}=R_{0}+R_{i}+R_{w}=R_{S}
$$


where

$$
\begin{aligned}
R_{0}= & \text { Resistance to heat transfer of fluid on the outside } \\
& \text { of the finned tube; } \\
R_{i}= & \text { Resistance to heat transfer of fluid on the inside } \\
& \text { of the tube; } \\
R_{w}= & \text { Resistance to heat transfer of the fin; } \\
R_{S}= & \text { Resistance to heat transfer of the scale; } \\
= & t_{s} / k_{s}
\end{aligned}
$$

where

$$
\begin{aligned}
& t_{s}=\text { scale thickness, ft; } \\
& k_{s}=\text { thermal conductivity of scale, Btu/hr-ft }{ }^{2}-{ }^{\circ} \mathrm{F} / \mathrm{ft} .
\end{aligned}
$$

The thermal conductivity of porous calcium carbonate is about 0.2 $\mathrm{Btu} / \mathrm{hr}-\mathrm{ft}{ }^{2}-{ }^{\circ} \mathrm{F} / \mathrm{ft},{ }^{(7)}$ while that of aluminum is about $118 \mathrm{Btu} / \mathrm{hr}-\mathrm{ft}^{2}{ }^{\circ} \mathrm{F} / \mathrm{ft} .{ }^{(8)}$ Thus, small calcium carbonate scale deposits may significantly reduce the cooling efficiency of a deluged system. Table 1 shows the reduction in the overall heat transfer coefficient as a function of calcium carbonate scale thickness for the three dry cooling systems under study. Since fin spacing (except in the plastic system, which has no fins) is $6.83 \mathrm{x}$ $10^{-3} \mathrm{ft}(2.08 \mathrm{~mm})$, scale thickness (on each side of the fin) greater than about $1.5 \times 10^{-3} \mathrm{ft}(0.5 \mathrm{~mm})$ will hamper delugate flow and thus further reduce heat transfer. 
TABLE 1. Reduction in Heat Transfer Coefficient Resulting From Calcium Carbonate Scale in Deluged DCT Systems.

\begin{tabular}{|c|c|c|c|c|}
\hline \multirow[b]{2}{*}{ Thickness, ft } & \multirow[b]{2}{*}{$\begin{array}{l}\text { Resistance, }{ }^{R} \\
\mathrm{Hr}-\mathrm{ft}^{2}-{ }^{\circ} \mathrm{F} / \mathrm{BTU}^{\mathrm{S}}\end{array}$} & \multicolumn{3}{|c|}{$\begin{array}{c}\text { Overal1 Heat Transfer } \\
\text { Coefficient, } \mathrm{U}, \\
\text { BTU/hr-ft }-{ }^{\circ} \mathrm{F}\end{array}$} \\
\hline & & $\begin{array}{l}\text { Water, } \\
\text { Norma1 } \\
\text { System(a) }\end{array}$ & $\begin{array}{l}\text { Ammonia } \\
\text { System(b) }\end{array}$ & $\begin{array}{l}\text { Water, } \\
\text { Plastic } \\
\text { System (c) }\end{array}$ \\
\hline 0 & 0 & 5.01 & 6.56 & 15.18 \\
\hline $1.0 \times 10^{-5}$ & $5.0 \times 10^{-5}$ & 5.006 & 6.555 & 15.171 \\
\hline $5.0 \times 10^{-5}$ & $2.5 \times 10^{-4}$ & 5.001 & 6.547 & 15.125 \\
\hline $1.0 \times 10^{-4}$ & $5.0 \times 10^{-4}$ & 4.995 & 6.536 & 15.068 \\
\hline $5.0 \times 10^{-4}$ & $2.5 \times 10^{-3}$ & 4.945 & 6.452 & 14.627 \\
\hline $1.0 \times 10^{-3}$ & $5.0 \times 10^{-3}$ & 4.885 & 6.349 & 14.111 \\
\hline $5.0 \times 10^{-3}$ & $2.5 \times 10^{-2}$ & 4.450 & 5.634 & 11.005 \\
\hline
\end{tabular}

(a) Carbon steel tubes, extruded aluminum fins

(b) Aluminum tubes and fins

(c) Bare plastic tubes

\subsection{THEORY OF CALCIUM CARBONATE SCALE FORMATION}

\subsection{SCALING INDEXES}

Most water treatment programs designed to control calcium carbonate scale formation in cooling water systems are based on the use of the Langlier Saturation Index. ${ }^{(9)}$ This index makes it possible to predict the tendency of a given water at equilibrium to either deposit calcium carbonate scale from solution or to dissolve calcium carbonate with which the water is brought into contact. (10) The index takes into 
account the water's calcium content, alkalinity, pH, dissolved solids and temperature. Other factors affecting scale formation which the Saturation Index does not account for include rate of heat transfer and concentration of magnesium, sulfate, phosphate and silica. While the index does include a factor for total dissolved solids, it does not distinguish among the various ions in solution; rather, all ions are treated as having the same effect on scaling.

For waters in the $\mathrm{pH}$ range of 6.5 to 9.5 , Langlier's equation for the pH at which the solution is in equilibrium with respect to calcium carbonate is as follows: ${ }^{(9)}$

$$
\mathrm{pH}_{\mathrm{S}}=\left(\mathrm{pK}_{2}^{\prime}-\mathrm{pK} \mathrm{K}_{\mathrm{S}}^{\prime}\right)+\mathrm{pCa}+\mathrm{pAlk}
$$

where

$$
\begin{aligned}
\mathrm{pH}_{\mathrm{S}}= & \text { the } \mathrm{pH} \text { at calcium carbonate saturation; } \\
\mathrm{pK}_{2}^{\prime}= & \text { the negative logarithm of the second dissociation } \\
& \text { constant for carbonic acid, corrected for the ionic } \\
& \text { strength and temperature of the solution; } \\
\mathrm{pK}_{\mathrm{S}}^{\prime}= & \text { the negative logarithm of the solubility product for } \\
& \text { calcium carbonate, also corrected for the ionic strength } \\
& \text { and temperature; } \\
\mathrm{pCa}= & \text { the negative logarithm of the molal calcium concentration; } \\
\mathrm{pAlk}= & \text { the negative logarithm of the total alkalinity expressed } \\
& \text { as equivalents per liter. }
\end{aligned}
$$

The values of $\mathrm{pH}_{1}, \mathrm{pK}_{2}$, and $\mathrm{pK}_{\mathrm{S}}$ for various temperatures are given in Table 2. (12-14) Corrections for ionic strength $(\mu)$ are given in Table 3! $(14,15)$ 
TABLE 2. Equilibrium Values of the Solubility Constant of $\mathrm{CO}_{2}\left(\mathrm{~K}_{H}\right)$, the Dissociation Constants of Carbonic Acid $\left(k_{1}\right.$ and $\left.k_{2}\right)$ and the Solubility Product of Calcium Carbonate $\left(K_{s}\right)$ as They Vary with Temperature.

\begin{tabular}{|c|c|c|c|c|}
\hline Temperature $\left(\mathrm{C}^{\circ}\right)$ & $\mathrm{pK}_{\mathrm{H}}$ & $\mathrm{pK}_{1}$ & $\mathrm{pK}_{2}$ & $\mathrm{pK}_{\mathrm{S}}$ \\
\hline 0 & 1.11 & 6.577 & 10.625 & 8.023 \\
\hline 5 & 1.19 & 6.517 & 10.557 & 8.087 \\
\hline 10 & 1.27 & 6.465 & 10.490 & 8.150 \\
\hline 15 & 1.32 & 6.420 & 10.430 & 8.215 \\
\hline 20 & 1.41 & 6.382 & 10.377 & 8.280 \\
\hline 25 & 1.47 & 6.351 & 10.329 & 8.342 \\
\hline 30 & 1.53 & 6.327 & 10.290 & 8.395 \\
\hline 40 & 1.64 & 6.296 & 10.220 & 8.515 \\
\hline 50 & 1.72 & 6.287 & 10.172 & 8.625 \\
\hline 80 & -- & $(6.315)$ & $(10.122)$ & 8.975 \\
\hline
\end{tabular}

The Saturation Index is defined as the algebraic difference between the actual measured $\mathrm{pH}$ of the water $\left(\mathrm{pH}_{\mathrm{a}}\right)$ and the calculated $\mathrm{pH}_{\mathrm{S}}$ at calcium carbonate equilibrium:

$$
\text { Saturation Index }=\mathrm{pH}_{\mathrm{a}}-\mathrm{pH}_{\mathrm{s}} \text {. }
$$

The index qualitatively shows the tendency for deposition or solution of calcium carbonate. A positive Saturation Index indicates a tendency to deposit calcium carbonate, while a negative value indicates an undersaturated condition and a tendency to dissolve existing calcium carbonate scale. Waters with a negative Saturation Index do not form a protective scale; common cooling water practice ${ }^{(11)}$ is to maintain a slightly positive ( $~ 1.0)$ Saturation Index to minimize corrosion. 
TABLE 3. Ionic Strength Corrections of the Ionization Constants of Carbonic Acid and the Solubility Product of Calcium Carbonate.

$$
\begin{aligned}
& \mathrm{pK}_{1}^{\prime}=\mathrm{pK}_{1}-\frac{0.5 \sqrt{\mu}}{1+1.4 \sqrt{\mu}} \\
& \mathrm{pK}_{2}^{\prime}=\mathrm{pK}_{2}-\frac{2.0 \sqrt{\mu}}{1+1.4 \sqrt{\mu}} \\
& \mathrm{pK}_{S}^{\prime}=\mathrm{pK}_{S}-\frac{4.0 \sqrt{\mu}}{1+3.9 \sqrt{\mu}}
\end{aligned}
$$

The Ionic Strength $(\mu)$ can be estimated from

$$
\begin{aligned}
H & =10^{-5}[4(\mathrm{TH})-\mathrm{A}] \text {, where } \\
\mathrm{TH} & =\text { Total Hardness in } \mathrm{mg} / 1 \text { as } \mathrm{CaCO}_{3} ; \\
\mathrm{A} & =\text { Total Alkalinity in } \mathrm{mg} / 1 \text { as } \mathrm{CaCO}_{3} ;
\end{aligned}
$$

or, for waters of less than $500 \mathrm{mg} / 1$ dissolved solids,

$$
\begin{aligned}
& \mu=S \times\left(2.5 \times 10^{-5}\right) \text {, where } \\
& S=\text { Dissolved Solids in mg/l. }
\end{aligned}
$$

Various nomographs have been prepared to simplify the calculation of $\mathrm{pH}_{\mathrm{S}}$. A nomograph suitable for this purpose is shown in Figure $1 ;{ }^{(10)}$ a sample Saturation Index calculation is included therein.

Langlier's Saturation Index was revised by Ryznar ${ }^{(17)}$ in an attempt to provide an index which would give quantitative scaling information. His Stability Index is defined by the empirical formula

$$
\text { Stability Index }=2 \mathrm{pH}_{\mathrm{s}}-\mathrm{pH}_{\mathrm{a}} \text {. }
$$




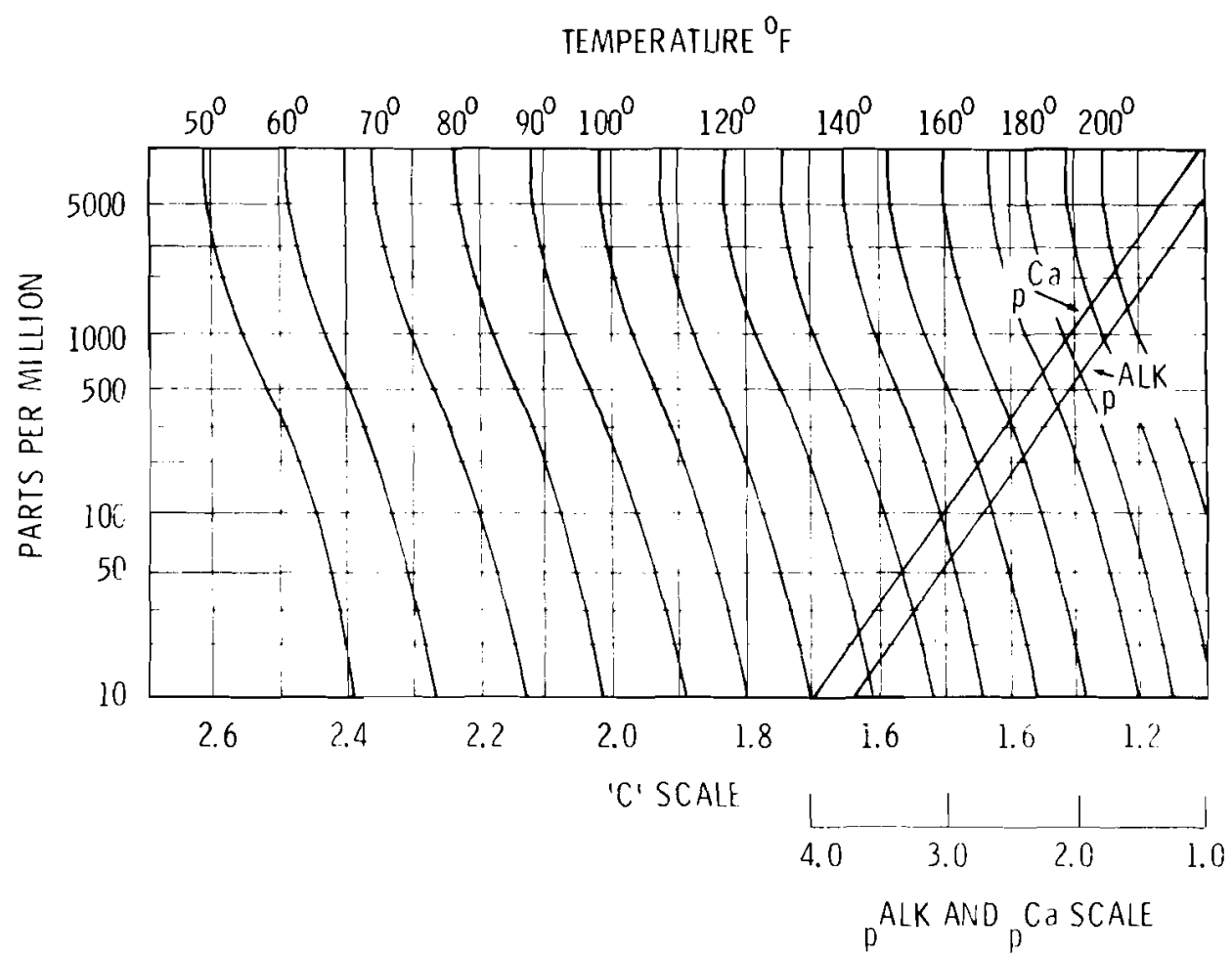

FIGURE 1. Langelier Saturation Index Chart.

To Determine:

pCa: Locate ppm value for $\mathrm{Ca}$ as $\mathrm{CaCO}_{3}$ on the ppm scale. Proceed horizontally to ${ }^{3}$ the left diagonal line down to the pCa scale.

pALK: Locate ppm value for 'M'ALK as $\mathrm{CaCO}_{3}$ on the ppm scale. Proceed horizontally to the right diagonal line down to the pALK scale.

Total Solids: Locate ppm value for total solids on the ppm scale. Proceed horizontally to the proper temperature 7 ine and down to the ' $C$ ' scale.

Example:

Temp. $=140 \mathrm{~F} . \mathrm{pH}-7.80$
Ca Hardness $=200 \mathrm{ppm}$
M Alkalinity $=160 \mathrm{ppm}$
Total Solids $=400 \mathrm{ppm}$

$\begin{array}{ll}\mathrm{pCa}= & 2.70 \\ \mathrm{pALK}= & 2.50 \\ \mathrm{C} \text { at } 140 \mathrm{~F}= & \frac{1.56}{6.76} \\ \text { Sum }=\mathrm{pH}_{\mathrm{S}}= & 7.80 \\ \text { Actual ph }= & \frac{7.80}{1.04} \\ \text { Difference }= & +\frac{1.04}{} \text { Saturation Index }\end{array}$


For waters having a Stability Index of 6.0 or less, scaling increases and the tendency to corrosion decreases. When the Stability Index is above 7.0 , a protective coating of calcium carbonate scale may not be developed, and corrosion becomes an increasing problem as values increase above $7.5 .(10)$

\subsection{CRITICAL PH FOR SCALE FORMATION}

In Feitler's recent work, ${ }^{(18)}$ the theory is postulated that

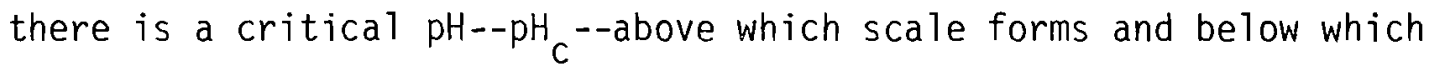
scale does not form. This work points out that the Langlier Saturation Index is based on the solubility of solid calcium carbonate and thus does not adequately predict the point at which precipitation actually occurs in the absence of particles of visible size. Feitler's work has shown that the critical $\mathrm{pH}, \mathrm{pH}_{\mathrm{C}}$, the $\mathrm{pH}$ at which calcium carbonate precipitation actually occurs, is about 1.7 to $2.0 \mathrm{pH}$ units above the saturation $\mathrm{pH}$, $\mathrm{pH}_{\mathrm{S}}$. The critical $\mathrm{pH}$ of a water can be determined using a scale meter described by Feitler.

Figure 2 shows how the solubility of calcium carbonate varies with temperature and concentrations of calcium and alkalinity. (19) The solid line represents a saturated solution, with the area below the curve being unsaturated. The Saturation Index is a means for determining the position of this line, and provides information about the amount of calcium carbonate that will remain in solution in the presence of solid $\mathrm{CaCO}_{3}$. The area above this curve is supersaturated and is divided into two regions. In the metastable region, small unstable nuclei form and dissolve without crystal growth. 


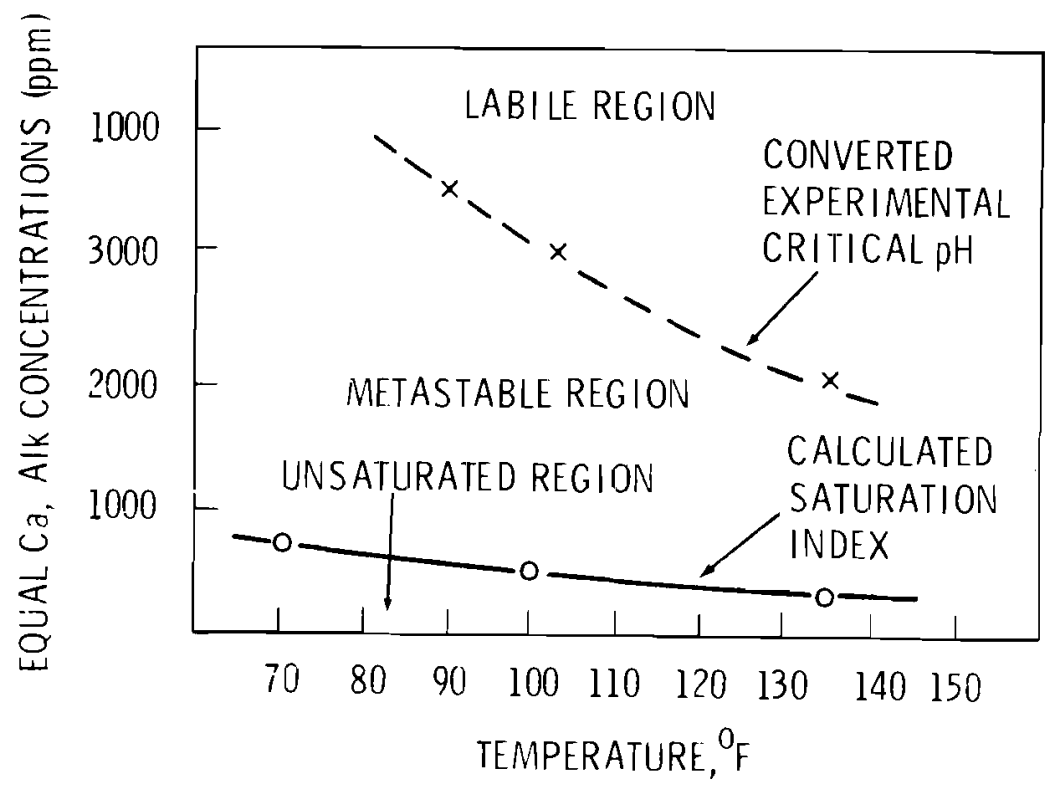

FIGURE 2. Calcium Carbonate Solubility Diagram

In the labile region. nuclei large enough to capture particles form, and crystal growth occurs. The critical pH defines the line separating the metastable and labile regions, and it predicts the amount of dissolved calcium carbonate which must be present for precipitation to take place in the absence of solid $\mathrm{CaCO}_{3}$.

The water reuse possibilities predicted by the various scaling indexes are shown in Figure 3. ${ }^{(11)}$ The Saturation Index curve is a plot of $\mathrm{pH}_{\mathrm{s}}$ calculated in the usual way, the Stability Index curve is plotted as $2 \mathrm{pH}_{\mathrm{s}}-6$, the Usual Practice curve as $\mathrm{pH}_{\mathrm{s}}+1$, and the Critical $\mathrm{pH}$ curve is a plot of experimental data. A temperature of $49^{\circ} \mathrm{C}\left(120^{\circ} \mathrm{F}\right)$ was used in all cases. Taking the prediction of the Saturation Index at pH 7.5 as one cycle of concentration, the plotted data show the wide variation in water reuse that is predicted by these various indexes. 


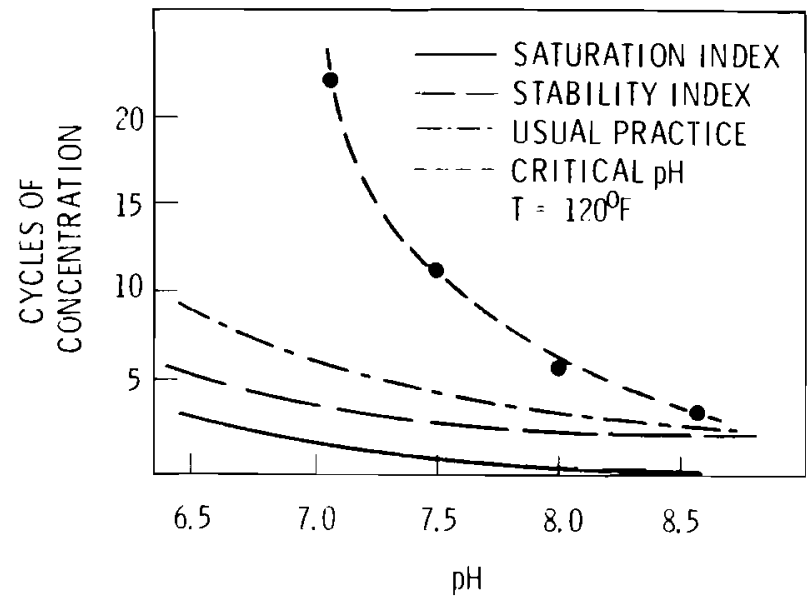

FIGURE 3. Scaling Predictions of Various Indexes.

The data used to generate the critical pH curve are shown in Table 4. From the observed $\mathrm{pH}_{\mathrm{C}}$ data the free $\mathrm{CO}_{3}{ }^{--}$concentration was calculated. This made it possible to calculate a critical scaling constant, $\mathrm{K}_{\mathrm{pHc}}$, the product of the calcium and free carbonate ion concentrations at $\mathrm{pH}_{\mathrm{c}}$. The average value of this constant, $1.8 \times 10^{-7}$, is 75 times larger than the solubility product $\left(K_{S}\right)$ of calcium carbonate as given in Table $1\left(2.37 \times 10^{-9}\right)$ at $50^{\circ} \mathrm{C}$. Since $K_{S}$ is the major factor in the Saturation Index, it is apparent that using the $\mathrm{K}_{\mathrm{pHc}}$ value allows the use of much higher calcium/alkalinity values. 
TABLE 4. Experimental Values of the Critical $\mathrm{pH}, \mathrm{pH}_{\mathrm{C}}$, and the Critical Scaling Constant, $\mathrm{K}_{\mathrm{pHc}}$, for $\mathrm{CaCO}_{3}$.

\begin{tabular}{|c|c|c|c|c|c|}
\hline $\begin{array}{c}\mathrm{Ca} \\
(\mathrm{ppm} \\
\left.\text { as } \mathrm{CaCO}_{3}\right)\end{array}$ & $\begin{array}{c}\mathrm{Alk} \\
(\mathrm{ppm} \\
\left.\text { as } \mathrm{CaCO}_{3}\right)\end{array}$ & $\mathrm{pH}_{\mathrm{c}-}$ & $\left(\mathrm{CO}_{3}^{-}\right)$ & $\left(\mathrm{Ca}^{++}\right)$ & $\mathrm{k}_{\text {phc }}$ \\
\hline 2000 & 2000 & 7.10 & $1.02 \times 10^{-5}$ & $2 \times 10^{-2}$ & $2.04 \times 10^{-7}$ \\
\hline 2000 & 1100 & 7.38 & $1.12 \times 10^{-5}$ & $2 \times 10^{-2}$ & $2.25 \times 10^{-7}$ \\
\hline 1000 & 1000 & 7.49 & $1.39 \times 10^{-5}$ & $10^{-2}$ & $1.39 \times 10^{-7}$ \\
\hline 500 & 500 & 8.00 & $2.14 \times 10^{-5}$ & $5 \times 10^{-3}$ & $1.07 \times 10^{-7}$ \\
\hline 300 & 300 & 8.64 & $6.90 \times 10^{-5}$ & $3 \times 10^{-3}$ & $2.10 \times 10^{-7}$ \\
\hline
\end{tabular}

It must be emphasized that $\mathrm{K}_{\mathrm{s}}$ and $\mathrm{K}_{\mathrm{pHc}}$ are values representing different physical realities. The solubility product, $K_{s}$, defines the amount of calcium and carbonate which remain in solution in the presence of solid $\mathrm{CaCO}_{3}$; the critical scaling constant, $\mathrm{K}_{\mathrm{pHc}}$, defines the amount of calcium and carbonate which, in the absence of solid $\mathrm{CaCO}_{3}$, must be in solution before scaling can occur.

\subsection{EFFECT OF MAGNESIUM AND SULFATE IONS ON CALCIUM CARBONATE SOLUBILITY}

It is known that increasing the concentration of the common ion (in this case either $\mathrm{Ca}^{++}$or $\mathrm{CO}_{3}^{--}$), which occurs as the cycles of concentration are increased, causes scaling to occur. Increasing the concentration of ions not common to the scale forming compound, however, increases the solubility of that compound. This phenomenon, the salt effect, is taken into account in the Saturation Index in terms of a 11 noncommon ions having an equal effect on solubility. 
The fact that all noncommon ions do not have an equal effect on calcium carbonate solubility is pointed out by the work of Akin and Lagerwerff. ${ }^{(20)}$ These workers demonstrated that both magnesium and sulfate ions enhance the solubility of calcite relative to its theoretical solubility, with magnesium having the greater effect. A plot showing the relation between the solubility product enhancement factor, E, and the ratio $r_{\mathrm{Mg}}=\left[\mathrm{Mg}^{++}\right] /\left[\mathrm{Ca}^{++}\right]$is given in Figure $4 .{ }^{(20)}$

Feitler has also shown that magnesium and sulfate ions have an effect on the critical scaling constant, $\mathrm{K}_{\mathrm{pHc}}$, with magnesium having a far greater effect. (11) The relationship between $\mathrm{K}_{\mathrm{pHc}}$ and concentrations of magnesium and sulfate is shown in Figure 5 .

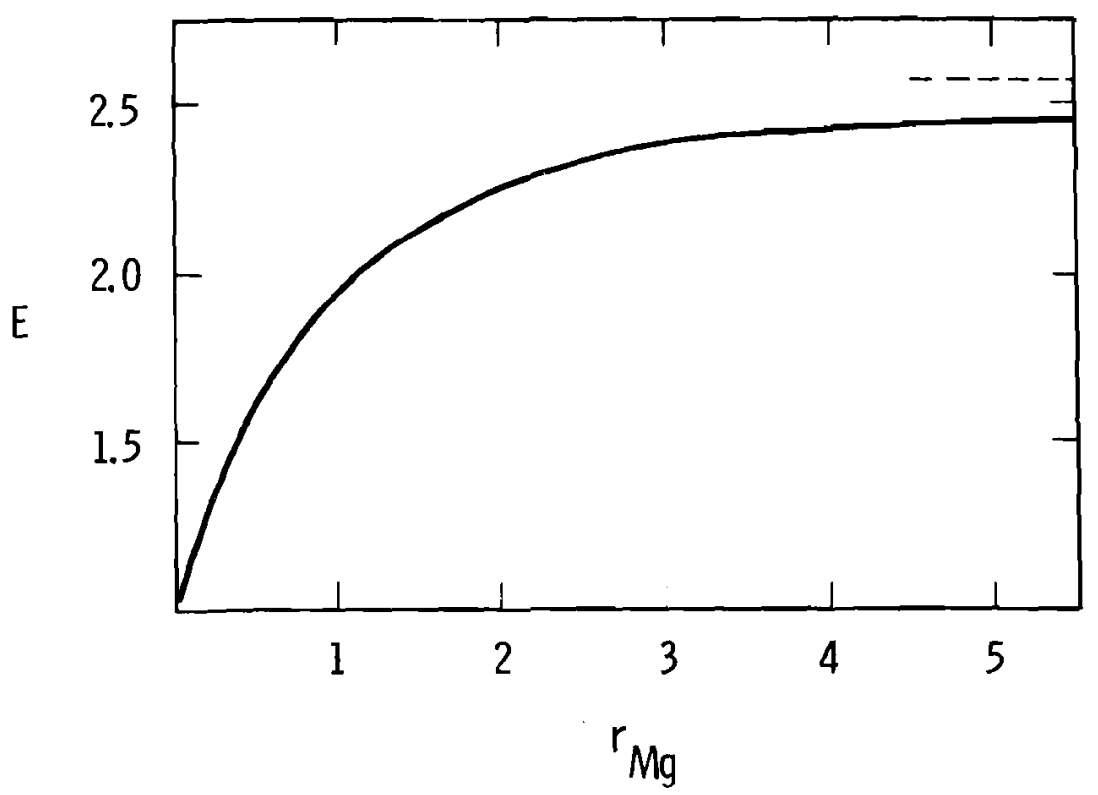

FIGURE 4. Relation Between the Solubility Product Enhancement Factor E, and the Equilibrium Ratio $r_{\mathrm{Mg}}=\left[\mathrm{Mg}^{2+}\right] /\left[\mathrm{Ca}^{2+}\right]$. 


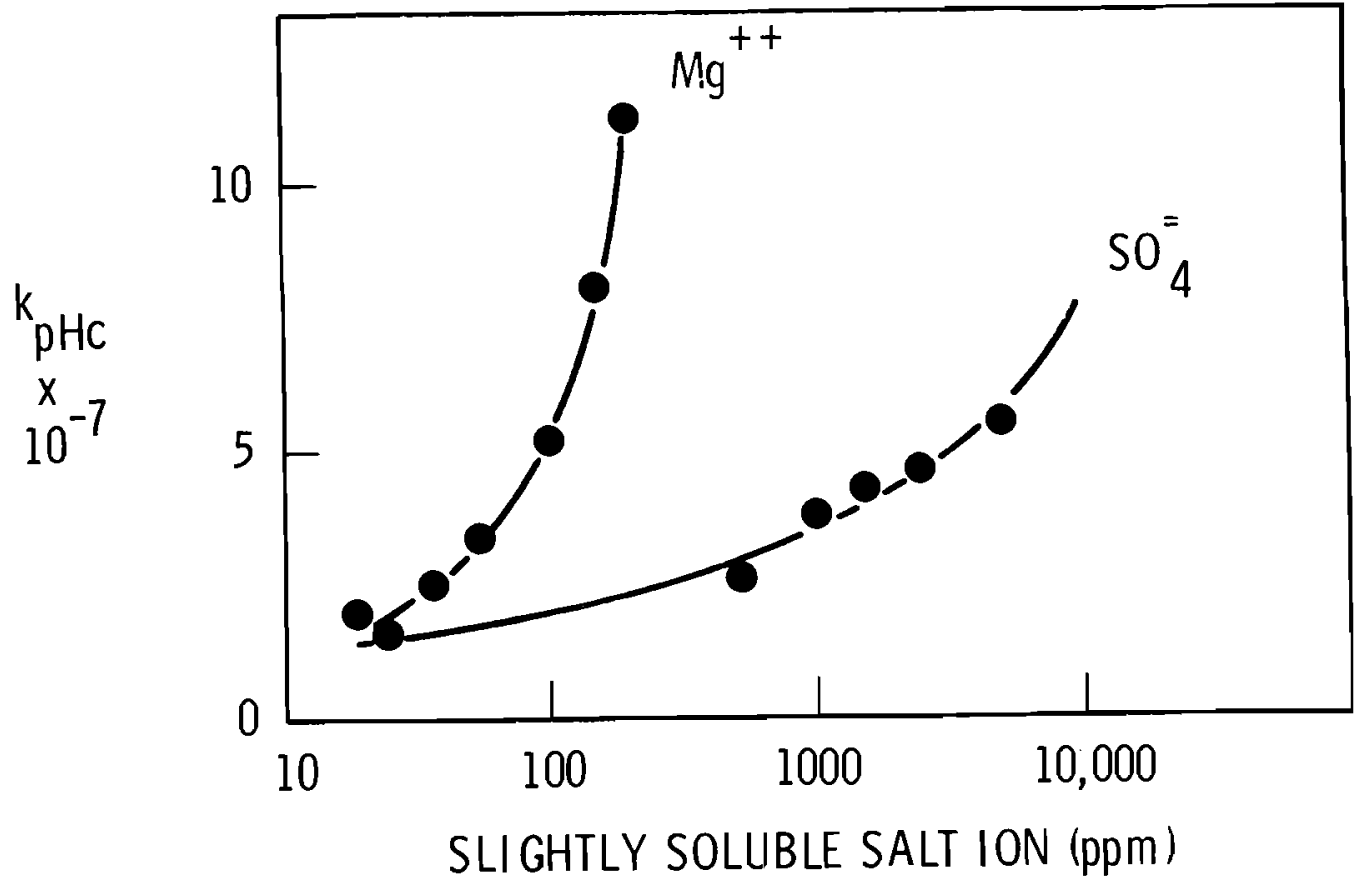

FIGURE 5. Magnesium and Sulfate Ion Effects On the Critical Scaling Constant, $\mathrm{K}_{\mathrm{pHc}}$.

\subsection{APPLICABILITY OF SCALING THEORY TO DELUGED DCT SYSTEMS}

\section{1 "PURE" DELUGATE MAKEUP}

From the above discussion it is apparent that the critical scaling constant $\mathrm{K}_{\mathrm{pHc}}$, should be used to determine that delugate quality which will assure no formation of calcium carbonate scale. The delugate will become scale forming when the product of the calcium ion and free carbonate ion molar concentrations exceeds $\mathrm{K}_{\mathrm{pHc}}$. 
Table 5 shows a water, arbitrarily given the designation "pure", that can usually be attained through the use of 1 ime softening, hot process lime soda softening, hot process lime soda softening, reverse osmosis or demineralization, depending on the raw water quality. (21) The cost of treating raw water to this quality ranges from $\$ 0.27$ to $\$ 0.92$ per 1000 gallons, depending on the raw water quality and treatment methodology. Further information on the cost of treating water is given in Appendix A-1.

TABLE 5. "Pure" Water Quality.

$\begin{array}{ll}\text { Total Hardness } & 20-40 \mathrm{mg} / 1 \text { as } \mathrm{CaCn}_{3} \\ \text { Calcium Hardness } & 15-30 \mathrm{mg} / 1 \text { as } \mathrm{CaCO}_{3} \\ \text { Total Alkalinity } & 10-25 \mathrm{mg} / 1 \text { as } \mathrm{CaCO}_{3} \\ \text { Sulfate } & 10-15 \mathrm{mg} / 1 \text { as } \mathrm{CaCO}_{3} \\ \text { Total Dissolved Solids } & 50-100 \mathrm{mg} / 1 \\ \mathrm{pH} & 7.5-8.0\end{array}$

For the purpose of the following discussion, it will be assumed that water of the quality described in Table 5 will be used as the original delugate and as delugate makeup water. Figure 6 shows the distribution of solute species, in moles/liter, as a function of $\mathrm{pH}$ after the above water in contact with the atmosphere has been allowed to concentrate, as a result of evaporation, to an impurity level 35 times greater than that shown in Table 5 (e.g., 35 cycles of concentration). 


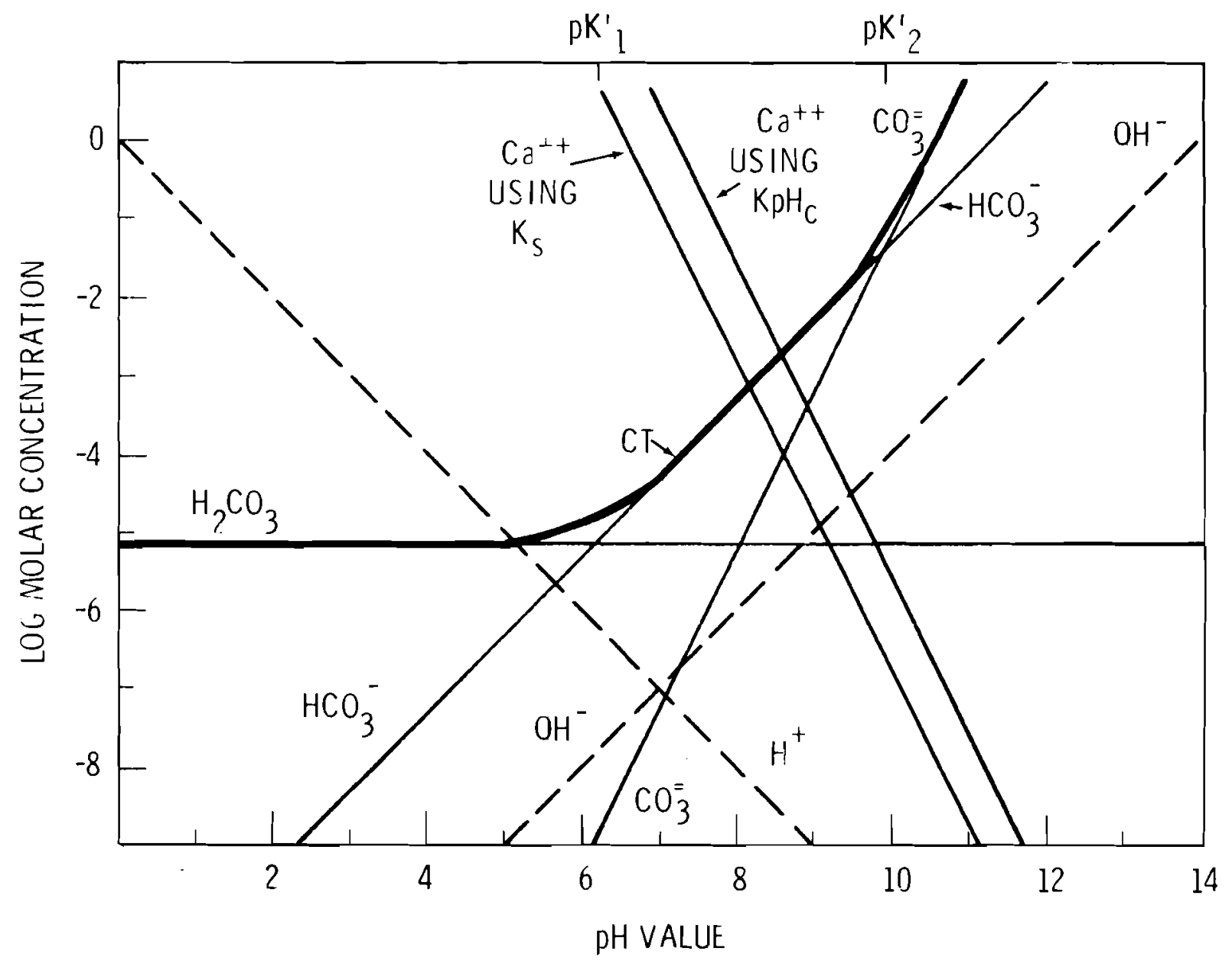

FIGURE 6. Aqueous Carbonate Equilibrium and Solubility of Calcium Carbonate as a Function of $\mathrm{pH}$ in a System Open to the Atmosphere; Ionic Strength $=0.035$, Temperature $=40^{\circ} \mathrm{C}$. 
The set of equations needed to construct this diagram are after Stumm and Morgan ${ }^{(14)}$ and are given in Table 6. All calculations are based on a circulating delugate temperature of $40^{\circ} \mathrm{C}\left(104^{\circ} \mathrm{F}\right)$ and an ionic strength of 0.035 .

If delugate of this quality is allowed to come to equilibrium, the pH will stabilize at about 8.6 , calcium hardness at about $10 \mathrm{mg} / 1$ as $\mathrm{CaCO}_{3}$, and total alkalinity at about $90 \mathrm{mg} / 1$ as $\mathrm{CaCO}_{3}$. Thus, about $1000 \mathrm{mg}$ of calcium per liter will have precipitated out as calcium carbonate scale. If the water film thickness on the deluged surfaces is $0.25 \mathrm{~mm}\left(0.01\right.$ inch) thick, the initial $\mathrm{CaCO}_{3}$ scale will be about $1.45 \times 10^{-4} \mathrm{~mm}\left(4.8 \times 10^{-7} \mathrm{ft}\right)$ thick assuming a $\mathrm{CaCO}_{3}$ density of $1.75 \mathrm{~g} / \mathrm{cm}^{3}$. With a delugate makeup rate of $4000 \mathrm{gpm}$, scale thickness will increase at a rate of about $4.3 \times 10^{-4} \mathrm{~mm} /$ day $\left(1.9 \times 10^{-6} \mathrm{ft} / \mathrm{day}\right)$; the unacceptable level of $0.5 \mathrm{~mm}\left(1.5 \times 10^{-3} \mathrm{ft}\right)$ of scale will be reached after about 3.2 years of continuous operation. 
TABLE 6. The Equilibrium Distribution of Solutes in Delugate Water 0pen to the Atmosphere, Ionic Strength $=0.035$, Temperature $=40^{\circ} \mathrm{C}$.

Species: $\mathrm{Ca}^{++}, \mathrm{CO}_{2(\mathrm{aq})}, \mathrm{H}_{2} \mathrm{CO}_{3}, \mathrm{HCO}_{3}^{-}, \mathrm{CO}_{3}^{--}, \mathrm{H}^{+}, \mathrm{OH}^{-}$

Equilibrium Constants:

$$
\begin{aligned}
{\left[\mathrm{H}_{2} \mathrm{CO}_{3}\right] /\left[\mathrm{CO}_{2(\mathrm{aq})}\right] } & =\mathrm{K}_{\mathrm{H}}=2.2909 \times 10^{-2} \\
{\left[\mathrm{H}^{+}\right]\left[\mathrm{HCO}_{3}^{-}\right] /\left[\mathrm{H}_{2} \mathrm{CO}_{3}\right] } & =\mathrm{K}_{1}^{\prime}=5.9997 \times 10^{-7} \\
{\left[\mathrm{H}^{+}\right]\left[\mathrm{CO}_{3}^{--}\right] /\left[\mathrm{HCO}_{3}^{-}\right] } & =\mathrm{K}_{2}^{\prime}=1.1926 \times 10^{-10} \\
{\left[\mathrm{H}^{+}\right]\left[\mathrm{OH}^{-}\right] } & =\mathrm{K}_{\mathrm{W}}=1.00 \times 10^{-14} \\
{\left[\mathrm{Ca}^{++}\right]\left[\mathrm{CO}_{3}^{--}\right] } & =\mathrm{K}_{\mathrm{pHC}}=1.8 \times 10^{-7} \\
{\left[\mathrm{Ca}^{++}\right]\left[\mathrm{CO}_{3}^{--}\right] /\left[\mathrm{CaCO}_{3(\mathrm{~s})}\right] } & =\mathrm{K}_{\mathrm{S}}=8.273 \times 10^{-9}
\end{aligned}
$$

Concentrations ( 35 Cycles of Concentration):

$$
\begin{gathered}
\mathrm{PCO}_{2}=3.1623 \times 10^{-4} \\
\mathrm{C}_{\mathrm{T}}=[\mathrm{A} 1 \mathrm{k}]=\left[\mathrm{H}_{2} \mathrm{CO}_{3}\right]+\left[\mathrm{HCO}_{3}^{-}\right]+\left[\mathrm{CO}_{3}^{--}\right] \\
{\left[\mathrm{Ca}^{++}\right]=1.0 \times 10^{-2}}
\end{gathered}
$$

Ionization Fractions:

$$
\begin{aligned}
& {\left[\mathrm{H}_{2} \mathrm{CO}_{3}\right]=\mathrm{K}_{\mathrm{H}} \mathrm{P} \mathrm{CO}_{2}} \\
& {\left[\mathrm{HCO}_{3}{ }^{-}\right]=\frac{\mathrm{K}_{\mathrm{H}^{\mathrm{p}} \mathrm{CO}_{2} \mathrm{~K}_{1}^{\prime}}}{\left[\mathrm{H}^{+}\right]}} \\
& {\left[\mathrm{CO}_{3}{ }^{--}\right]=\frac{{ }^{{ }^{\prime}} \mathrm{P} \mathrm{CO}_{2}{ }^{\mathrm{K}_{1}^{\prime} \mathrm{K}_{2}^{\prime}}}{\left[\mathrm{H}^{+}\right]^{2}}} \\
& {\left[\mathrm{Ca}^{++}\right]=\frac{\mathrm{K}_{\mathrm{pHC}}\left[\mathrm{H}^{+}\right]^{2}}{\mathrm{~K}_{\mathrm{H}^{\mathrm{p}} \mathrm{CO}_{2}{ }_{2} \mathrm{~K}_{1}^{\prime} \mathrm{K}_{2}^{\prime}}}}
\end{aligned}
$$


From the value of the critical scaling constant, $\mathrm{K}_{\mathrm{pHc}}=1.8 \times 10^{-7}$, and the expression for the equilibrium concentration of calcium ion,

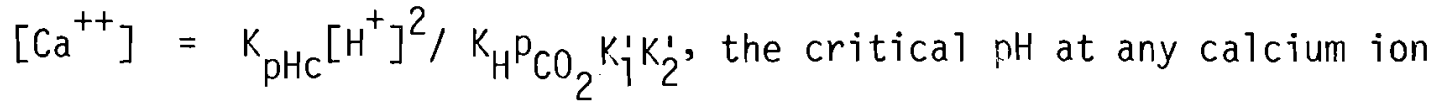
concentration can be calculated. At 35 cycles of concentration, $\left[\mathrm{Ca}^{++}\right]$ will be $1.05 \times 10^{-2}$ moles/liter, and $\mathrm{pH}_{\mathrm{C}}$ is 8.3 ; delugate at 35 cycles of concentration must be kept at a pH value less than 8.3 if scale formation is to be prevented.

Because of the uncertain conditions in cooling water systems, actual operation should be at some safe factor below this upper 1 imit. A conservative operating $\mathrm{pH}$ can be determined by substituting the value of the calcium carbonate solubility product, $K_{S}$, in the above expression and solving for the hydrogen ion concentration; the $\mathrm{pH}$ obtained in this way is 7.6. Thus, if water as described in Table 4 is used as delugate and is allowed to concentrate to 35 cycles of concentration, the $\mathrm{pH}$ should be maintained in the range of 7.6-7.8 to prevent the formation of calcium carbonate scale. This $\mathrm{pH}$ can be maintained by addition of sulfuric acid to the delugate.

The amount of blowdown required to maintain the above delugate qualily can be determined from (10)

where

$$
\% B=\frac{\% E}{(\text { cycles }-1)}
$$

$\% B=B$ lowdown expressed as percent of circulation rate;

$\% \mathrm{E}=$ Evaporation loss expressed as percent of circulation rate;

cycles $=$ Number of cycles of concentration 
Assuming an evaporation rate of $5 \%$, the amount of blowdown required is $0.15 \%$. If the delugate circulation rate if 78,700 gallons per minute, which is the approximate rate for a 1000 MWe plant, the required blowdown rate will be only about 120 gallons per minute.

\subsection{OTHER MAKEUP WATER QUALITIES}

Table 7 shows other water qualities and the cycles of concentration that can be safely allowed if scaling is to be avoided.

TABLE 7. Use of Various Waters as Delugate as a Function of !later nuality.

\section{Water}

Total Hardness, mg/l as $\mathrm{CaCO}_{3}$ Calcium Hardness, $\mathrm{mg} / 1$ as $\mathrm{CaCO}_{3}$ Total Alkalinity, $\mathrm{mg} / 1$ as $\mathrm{CaCO}_{3}$ Total Dissolved Solids, mg/l Allowed Cycles of Concentration Critical pH of Delugate Operating $\mathrm{pH}$ of Delugate Percent Blowdown required(a) Blowdown Rate, gpm(b) Columbia Richland

\begin{tabular}{|c|c|c|c|c|}
\hline "Pure" & River & City & River & Wyo. \\
\hline 40 & 60 & 95 & 220 & 295 \\
\hline 30 & 45 & 70 & 165 & 220 \\
\hline 25 & 60 & 50 & 235 & 420 \\
\hline 100 & 110 & 90 & 390 & 1550 \\
\hline 35 & 22 & 14 & 6.0 & 4.5 \\
\hline \multicolumn{5}{|c|}{ 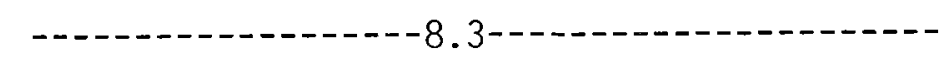 } \\
\hline$-\ldots$ & $--\ldots$ & $-7.6-7.8$ & ( & ----- \\
\hline 0.15 & 0.24 & 0.38 & 1.00 & 1.45 \\
\hline 120 & 190 & 305 & 790 & 1125 \\
\hline
\end{tabular}

(a) Assuming 5\% evaporation rate

(b) Assuming 1000 MWe plant with delugate circulation rate of $78,700 \mathrm{gpm}$

\subsection{SCALE FORMED RY DELUGATE EVAPORATION}

The extended surfaces of the dry cooling tower will be deluged only during warm periods to provide augmented cooling capability. When the dry bulb temperature drops below a specified point, the flow of delugate will be turned off and the tower will operate with the finned tube surfaces dry. 
When the delugate flow is turned off, the water remaining on the fin surfaces will evaporate, leaving behind as a scale all of the dissolved impurities it contained. Some of the salt so deposited, such as the compounds of sodium, will redissolve when the fins are again deluged. However, once calcium carbonate scale is formed, the solubility product, $K_{s}$, rather than the critical scaling constant, $K_{p H c}$, must be used to determine whether the scale will redissolve.

Assuming that the delugate quality is controlled as shown in Table 7 (pH 7.6-7.8, blowdown rate to ensure maximum calcium concentration of $1000 \mathrm{mg} / 1$ as $\left.\mathrm{CaCO}_{3}\right)$, the product of calcium and free carbonate molar concentrations will be equal to the solubility product of calcium carbonate at this temperature, and the scale will not redissolve. Since solid $\mathrm{CaCO}_{3}$ will then be present in the system, the pH must be lowered and maintained at about 7.2 to ensure no further scale formation.

Again assuming a water film thickness of $0.25 \mathrm{~mm},(0.01 \mathrm{inch})$ the thickness of calcium carbonate scale formed on evaporation of the delugate will be about $1.45 \times 10^{-4} \mathrm{~mm}\left(4.8 \times 10^{-7} \mathrm{ft}\right)$. Assuming that the delugate system is turned off and the water allowed to evaporate 200 times per year, an unacceptable amount of scale $(0.5 \mathrm{~mm})$ will build up in 17 years of operation. Thus the major incentive for preventing scale formation by evaporation is reduction in the amount of acid which would have to be added to prevent further deposition. Formation of calcium carbonate scale by evaporation of the delugate can be prevented by deluging the finned surfaces with zero hardness water before turning off the water flow. About 100,000 gallons of zero hardness water will be required for 
a five-minute flush. Capital cost of a sodium zeolite system to produce this water will be about $\$ 2.5 \times 10^{5}$; operating cost will be about $\$ 1.0 \times 10^{4}$ per year.

\subsection{DELUGATE TREATMENT FOR SCALE PREVENTION}

\subsection{SIDE-STREAM TREATMENT}

As has been indicated previously, a combination of acid treatment and concentration control is the preferred method for prevention of calcium carbonate scale in deluged DCT systems. Sulfuric acid is generally used in open recirculating water systems because of its low cost. (10)

A schematic drawing of the delugate system for a 1000 MWe plant is shown in Figure 7. (22) A side-stream taken from the delugate is treated by lime-soda softening. The allowed cycles of concentration, side-stream flow rate, and chemical dose rates will depend on the quality of the makeup water. Typical values are shown in Table 8 for a variety of waters.

Table 9 shows the costs of side-stream and makeup water treatment. $(21,22)$ As can be seen, it is considerably less expensive to use the existing raw water supply with $\mathrm{pH}$ control and side-stream treatment rather than to attempt to purify the makeup water.

\section{$6.2 \mathrm{pH}$ CONITROL}

The feed rate of $66^{\circ}$ Baume sulfuric acid to the makeup water can be calculated from the following formula (assuming a 12-hour 


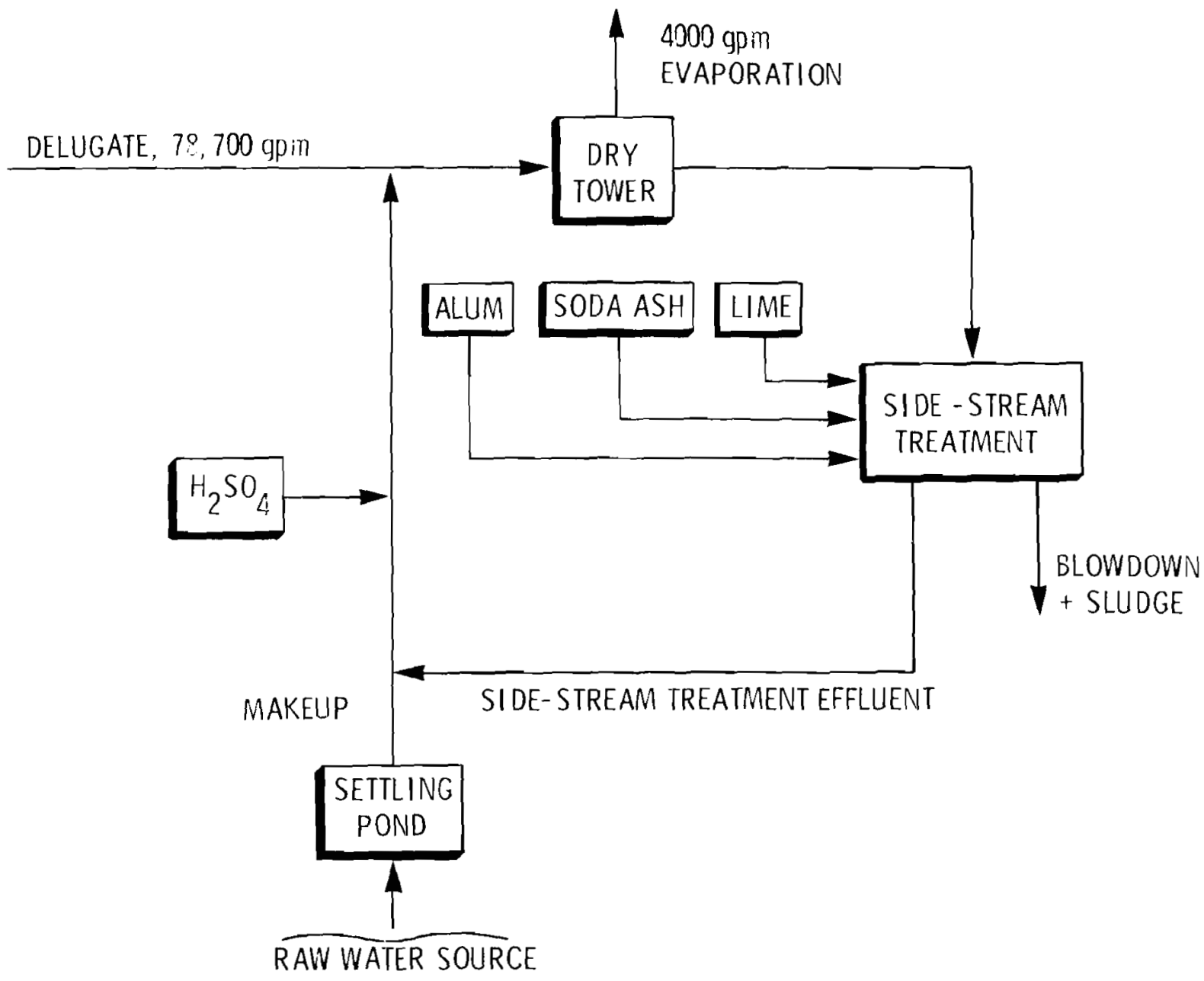

FIGURE 7. Treatment of Delugate Water to Prevent Formation of Calcium Carbonate Scale. 
day and a maximum allowed delugate alkalinity of $40 \mathrm{mg} / 1$ as $\left.\mathrm{CaCO}_{3}\right)$ :

$$
\begin{aligned}
& \text { gal. } \mathrm{H}_{2} \mathrm{SO}_{4} / \text { day }=\left(\Delta \mathrm{C}_{T}\right) \text { (Makeup Flow, gpm) }\left(4.12 \times 10^{-4}\right) \\
& \Delta C_{T}=\begin{array}{c}
\text { Alkalinity of Makeup, } \\
\text { mg/1 as } \mathrm{CaCO}_{3}
\end{array}
\end{aligned}
$$

where

Acid feed rate should be controlled using an automatic $\mathrm{pH}$ control system similar to that similar to that shown in Figure $8 .{ }^{(10)}$ A typical acid delivery, storage and transfer system is shown in Figure 9. (10)

TABLE 8. Approximate Chemical Dosage Rates and Treatment Stream Flow

\begin{tabular}{|c|c|c|c|c|}
\hline "Pure" & $\begin{array}{l}\text { Columbia } \\
\text { River }\end{array}$ & $\begin{array}{c}\text { Richland } \\
\text { City }\end{array}$ & $\begin{array}{l}\text { San Juan } \\
\text { River }\end{array}$ & $\begin{array}{c}\text { Sheridan } \\
\text { Wyo. }\end{array}$ \\
\hline
\end{tabular}
Rates as a Function of Makeup Water Quality.

Circulation Rate, gpm

Evaporation Rate, gpm

Allowed Cycles of Concentration

Side Stream Flow Rate, gpm

Lime Dosage, Ib/day

Soda Ash Dosage, 1b/day

Alum Dosage, 1b/day

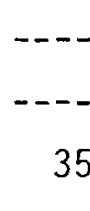

120

30

260

Blowdown + Sludge Flow Rate, gpm

Side-Stream Treatment Effluent Flow Rate, gpm

Makeup Flow Rate, gpm

Sulfuric Acid Feed Rate, gal/day

15

15

105

4015

40
$-78700$ $-4000$

305

305

6

4.5

190

75

790

1125

50

660

200

280

410

25

35

1710

2435

20

35

95

135

85

120

705

1005

4020

270

4085

4120

100

400

715 
TABLE 9. Approximate Costs of Side-Stream and Makeup Water Treatment.

$$
\text { "Pure" } \begin{gathered}
\begin{array}{c}
\text { Columbia Richland } \\
\text { River } \\
\text { City }
\end{array} \text { River Juan } \begin{array}{c}
\text { Sheridan } \\
\text { Wyo. }
\end{array} \\
\hline
\end{gathered}
$$

\begin{tabular}{|c|c|c|c|c|c|}
\hline Capital - $10^{4}$ Dollars & 7.8 & 10.0 & 14.0 & 24.0 & 30.0 \\
\hline Operating $-10^{4}$ Dollars/year ${ }^{(a)}$ & 1.0 & 1.6 & 2.5 & 6.4 & 9.1 \\
\hline
\end{tabular}

Side-Stream Treatment Costs:

Makeup Treatment Costs:
Capital - $10^{4}$ Dollars
Operating - $10^{4}$ Do11ars/year ${ }^{(a)} 14-38$
1.3
1.2
3.0
4.2
1.1
0.9
4.3
7.7

(a) Assuming operation at $80 \%$ capacity.

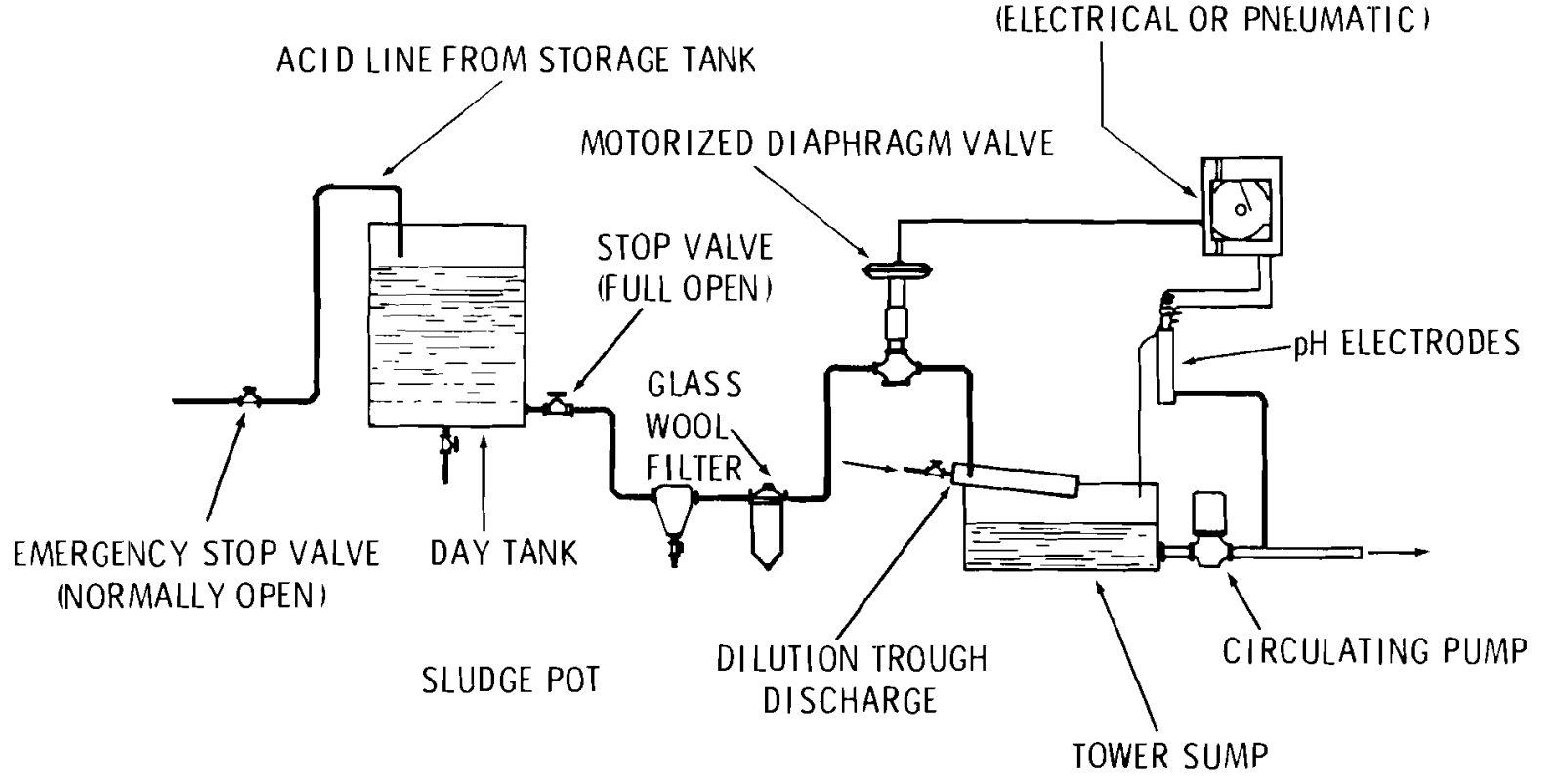

FIGURE 8. System for Automatic Control of Delugate pH. 


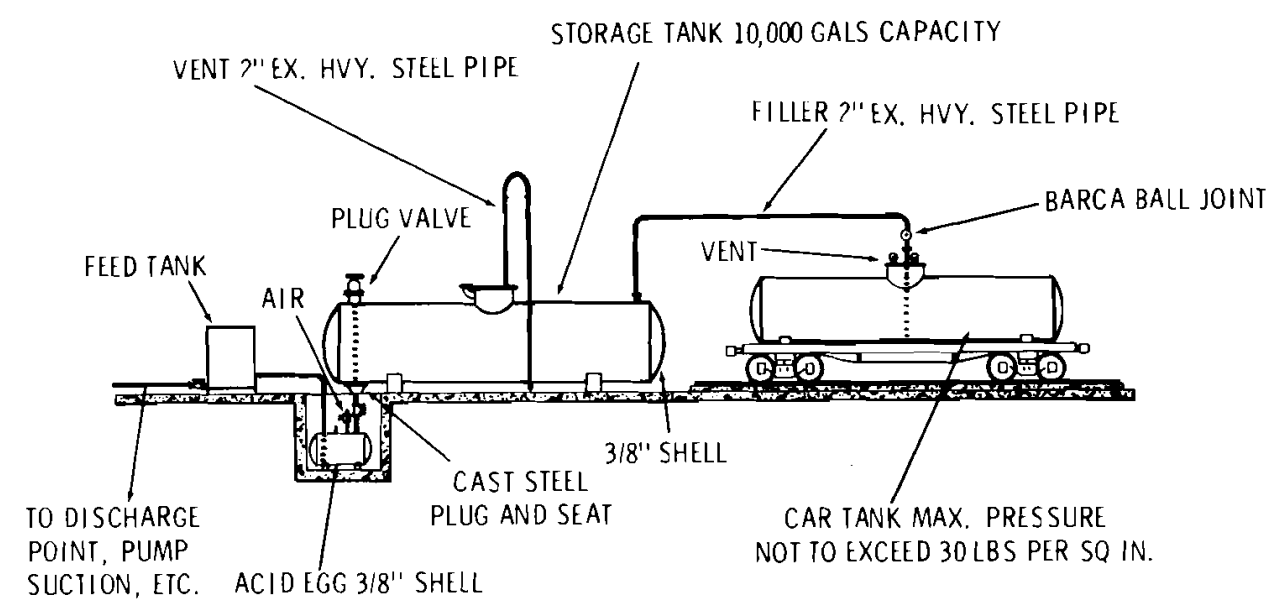

FIGURE 9. Acid Delivery, Storage and Transfer System.

\subsubsection{Calcium Sulfate Scale Formation}

Of concern with the use of sulfuric acid for $\mathrm{pH}$ control is the possibility of calcium sulfate scale formation. A water treatment consulting firm indicates that a good rule of thumb to control calcium sulfate scale is to never allow the product of the concentrations (in $\mathrm{mg} / 1$ as $\mathrm{CaCO}_{3}$ ) of calcium and sulfate ions to exceed 500,000. (23) However, Feitler ${ }^{(11)}$ has shown that between 5 and 10 times the solubility product concentrations are required before precipitation of calcium sulfate begins. From his data a critical scaling constant of about $2.5 \times 10^{-3}\left(\left[\mathrm{Ca}^{++}\right]\left[\mathrm{SO}_{4}^{--}\right]\right)$can be calculated for calcium sulfate. The concentrations of sulfate in the delugate for the various waters being considered are shown in Table 10. As this table shows, the ion product of calcium and sulfate is less than the critical scaling constant for each of the waters shown; therefore, calcium sulfate scale will not form. 
TABLE 10. Buildup of Sulfate Concentration in the Delugate as a Function of Makeup Water Quality.

Sulfate in Makeup Water:

$$
\begin{aligned}
& \text { "Pure" } \begin{array}{c}
\begin{array}{c}
\text { Columbia Richland } \\
\text { River } \\
\text { City }
\end{array} \text { River Juan } \\
\text { Ryo. Wheridan } \\
\hline
\end{array} \\
& \text { "Pure" } \begin{array}{c}
\text { Columbia Richland } \\
\text { River } \\
\text { City }
\end{array} \text { River Juan } \begin{array}{c}
\text { Sheridan } \\
\text { Wyo. }
\end{array}
\end{aligned}
$$

Natura 1:

Added:

Total :

Cycles of Concentration:

Sulfate in Delugate: (a)

Calcium in Delugate: ${ }^{(a)}$ $\left[\mathrm{Ca}^{++}\right] \times\left[\mathrm{SO}_{4}^{--}\right] \times 10^{4}:$

Critical Scaling Constant $\times 10^{4}$ :

(a)

$\begin{array}{rrrrr}15 & 25 & 35 & 175 & 735 \\ 26 & 62 & 53 & 245 & 435 \\ 40 & 87 & 88 & 420 & 1170 \\ 35 & 22 & 14 & 6 & 4.5 \\ 1400 & 1915 & 1230 & 2520 & 5265 \\ 1050 & 990 & 980 & 990 & 990 \\ 1.5 & 1.9 & 1.2 & 2.5 & 5.2\end{array}$

(a) $\mathrm{mg} / 1$ as $\mathrm{CaCO}_{3}$

\subsection{RESEARCH NEEDS}

1 - Not addressed in this paper are the degradation of deluge water quality and fouling of the finned surfaces by air-borne particulate material such as dust, insects, pollen, etc. A systematic study is needed of fouling propensity, cleaning techniques and increased sidestream treatment capacity necessitated by degraded air quality.

2 - Given here is an estimate of the effect of scale on heat transfer and delagate flow. Experimental data is needed to precisely define how much scale can be tolerated and rates of scale deposition as a function of water quality and treatment. 
3 - It is recommended herein that zero-hardness water be used to flush the extended surfaces at the end of each deluge cycle. When this water evaporates, a layer of inorganic salts will be deposited on the fin surfaces. Pitting corrosion of the aluminum fins beneath these salt deposits is possible during dry operation. nuestions which require laboratory analysis include the following:

- Does pitting beneath the salt deposits occur?

- What is the effect of pitting on the heat transfer performance of the extended surfaces?

- Will flushing with deionized water be required?

4 - An alternate delugate treatment technology is one employing dispersants (such as phosphonates, polyacylates, etc) to inhibit scale formation. While such materials are widely used as scale inhibitors in wet evaporative towers, their effectiveness in systems allowed to evaporate to dryness is unknown. Dispersants may aid in redissolution of materials deposited by evaporation, and this methodology may prove to be less expensive than control of $\mathrm{pH}$ and calcium concentration; laboratory data are required.

5 - Verification of the critical scaling constants, particularly that for calcium sulfate, is required. Accurate determination of these constants is needed as a function of temperature, ionic strength and noncommon ions such as magnesium. 
6 - It has been assumed that the alternate wet-dry cycles in the deluge system will control the growth of algae and other biofouling organisms in the system. This assumption requires experimental verification. If biofouling appears to be a problem, control procedures such as the use of chlorine and the use of supplementary biocides must be examined.

7 - The effect of finned-tube design on heat transfer degradation due to scale deposition and corrosion is largely unknown. The least expensive design is one employing aluminum fins wrapped on to carbon steel tubes. Whether this design will be subject to such problems as crevice corrosion, galvanic corrosion, scale formation in the crevice, etc. is an area requiring experimental work. Certainly exposed carbon steel tube ends will be subject to corrosion, and an effective means of protection must be devised.

\subsection{SUMMARY AND CONCLUSIONS}

Deluging of air-cooled heat exchangers with water during warm periods holds the promise of increasing their heat rejection capability and reducing the cost of dry cooling. One of the principal uncertainties in the use of the deluge concept is the tendency toward deposition of solids from the delugate. Small amounts of calcium carbonate scale may significantly reduce the cooling efficiency of a deluged system by reducing the heat transfer coefficient and interfering with delugate flow. Thus it is important to define delugate water quality in evaluating the formation of scale and its effect on heat transfer in the deluged dry cooling system. 
Most water treatment programs designed to control calcium carbonate scale formation in cooling water systems are based on the use of the Langlier Saturation Index. Recent work has shown that the Saturation Index is conservative, and open recirculating cooling systems can be operated at a pH level (the "critical pH") 1.7 to $2.0 \mathrm{pH}$ units above that predicted by the Saturation Index. The presence of magnesium and sulfate ions in the water increases the permissible operating $\mathrm{pH}$ even further. Operation at $\mathrm{pH}$ levels higher than those derived from the Saturation Index greatly increases the water reuse possibilities of a given raw water supply.

A.pplication of the critical pH concept together with carbonate equilibria in an open aqueous system makes possible the calculation of the concentration of all solute species at any pH. If an arbitrary upper limit of $1000 \mathrm{mg} / 1$ as $\mathrm{CaCO}_{3}$ for the calcium hardness is chosen, the system must be maintained at a pH level less than 8.3 if formation of calcium carbonate scale is to be prevented. Suggested safe operation is at a $\mathrm{pH}$ level somewhat lower than this upper limit, in the range of 7.6-7.8.

When the flow of delugate is turned off, water remaining on the surface will evaporate and deposit as a scale the impurities it contained. Calcium carbonate scale so deposited will not redissolve, since the ion product of calcium and free carbonate species in the delugate will be about equal to the solubility product. If further scale deposition is to be avoided, the delugate operating $\mathrm{pH}$ must be reduced to about $\mathrm{pH} 7.2$. 
Formation of calcium carbonate scale by evaporation of the delugate can be prevented by deluging the finned surfaces with zero hardness water before turning off the water flow.

The method of choice for the prevention of calcium carbonate scale in deluged DCT systems is a combination of $\mathrm{pH}$ control using sulfuric acid and concentration control by the use of side-stream treatment.

Areas requiring experimental data include the effect of air-borne particulates on heat exchanger fouling and degradation of delugate quality, a more precise definition of heat transfer degradation due to sealing and the amount of scale that can be tolerated, the effect of salt deposition on fin corrosion, the use of dispersants to control scale, verification of values of the critical scaling constants, the possibility of biofouling and the effect of finned tube design on scaling and corrosion problems. 


\section{REFERENCES}

1. W. J. Yang and D. W. Clark, "Spray Cooling of Air-Cooled Compact Heat Exchangers," Int. ‥ Heat Mass Transfer, 18, 311 (1975).

2. "Report of the United States of American Dry \& Dry/Wet Cooling Tower Delegation Visit to the Union of Soviet Socialists Republics," ERDA-105, (May 26-نune 7, 1975).

3. W. Kals, "Wet-Surface Aircoolers," Chemical Engineering, 78, 90 (July 26, 1971).

4. M. W. Larinoff, Vice President, Hudson Products, Inc., Personal Communication (Dec. 1975).

5. E. C. Smith and A. Y. Gunter, "Cooling Systems Combining Air and Water as the Coolant," ASME 72-HT-29 (Aug 1972).

6. J. Taborek, T. Aoki, R. B. Ritter, J.W. Palen and J. G. Knudsen, "Fouling: The Major Unresolved Problem in Heat Transfer, " Chemical Engineering Progress, 68 (2), 59 (1972).

7. C. B. Capper, "Fouling of Heat Exchangers from Cooling Water and Process Materials," Effluent and Water Treatment Journal, 14 (6), 309 (1974).

8. W. H. McAdams, Heat Transfer, McGraw-Hi11, New York (1942).

9. W. F. Langlier, "The Analytical Control of Anti-Corrosion Water Treatment," American Water Works Association Journal, 28 (10), 1500 (1936).

10. Betz Handbook of Industrial Water Conditioning, Sixth Edition, Betz Laboratories, Inc., Trevose, PA (1971).

11. H. Feitler, "Critical pH Scaling Indexes," Materials Performance, 14 (8), 33 (1975).

12. H. S. Harned and F. T. Bonner, "The First Ionization Constant of Carbonic Acid in Aqueous Solutions of Sodium Chloride," Journal of the American Chemical Society, 67, 1026 (1945).

13. H. S. Harned and S. R. Scholes, Jr., "The Ionization Constant of $\mathrm{HCO}_{3}{ }^{-}$ from 0 to $50^{\circ}, "$ Journal of the American Chemical Society, 63, 1706 ( 9941 ).

14. W. Stumm and J. J. Morgan, Aauatic Chemistry -- An Introduction Emphasizing Chemical Equilibria in :'atural Waters, Hiley-Interscience, We:N York, N.W. (1970). 
15. T. E. Larson and A. M. Buswe11, "Calcium Carbonate Saturation Index and A1kalinity Interpretations," American Water Works Association Journal, 34!11), 1667 (1942).

16. L. I. Pincus, Pratical Boiler Water Treatment, McGraw-Hill Book Co., Inc., New York, N.Y. p.227 (1962).

17. J. A. Ryznar, "A New Index for Determining the Amount of Calcium Carbonate Scale Formed by a Water," American Water Works Association Journal, 36 (4), 472 (1944).

18. H. Feitler, "The Scale Meter: A New Method for Determining the Critical pH of Scaling, "Materials Protection and Performance, 11 (1), 31 (1972).

19. H. Feitler, "Cooling Water Scale Control: The Scale Meter and the Critical pH of Scaling," Materials Protection and Performance, 11 (6), 29 (1972).

20. G. W. Akin and J. V. Lagerwerff, "Calcium Carbonate Equilibria in Solutions Open to the Air. II. Enhanced Solubility of $\mathrm{CaCO}_{3}$ in the Presence of $\mathrm{Mg}^{{ }^{2}}$ and $\mathrm{SO}_{4}{ }^{-}$, Geochimica et Cosmochimica Acta, 29, 353 (1965).

21. J. S. Nordin, Betz Environmental Engineers, Inc., Plymouth Meeting, PA, Personal Communication (Sept. 1975).

22. B. Chettle, Betz Laboratories, Inc., Los Angeles, CA, Personal Communication (May 1976).

23. E. S. Troscinski and R. G. Watson, "Controlling Deposits in WaterCooling Systems," Chemical Engineering, 77 (5) 125 (1970). 
APPENDIX A

COSTS 


\section{APPENDIX A}

\section{COSTS}

\section{A-1. WATER TREATMENT COSTS}

Following are tables which show the cost, in 1975 dollars, of treating raw water of varying quality to various purity levels. Table A-1 shows the capital, operating and total costs (in terms of $\$ / 1000$ gal) of a three-mgd treatment plant. Data are given for five raw water types and four treatment levels, which are defined in Tables A-2 and A-3. Information given here is based on data received from J. S. Nordin, Betz Environmental Engineers, Plymouth Meeting, PA. 
TABLE A-1. Water Treatment costs, 3-MGD Treatment Plant

(1975 Dollars).

\begin{tabular}{|c|c|c|c|c|c|}
\hline $\begin{array}{l}\text { Desired } \\
\text { Quality, } \\
\text { see } \\
\text { Table A-2 } \\
\end{array}$ & $\begin{array}{l}\text { Raw Water } \\
\text { Type } \\
\text { see } \\
\text { Table A-3 } \\
\end{array}$ & $\begin{array}{l}\text { Capitol } \\
\text { Cost, } \\
\$ \times 10^{-5} \\
\end{array}$ & $\begin{array}{c}\text { Capital } \\
\text { Cost, (a) } \\
\$ / 1000 \text { gal } \\
\end{array}$ & $\begin{array}{l}\text { Dperating } \\
\text { Cost, } \\
\$ / 1000 \text { gal }\end{array}$ & $\begin{array}{l}\text { Total } \\
\text { Cost, } \\
\$ / 1000 \text { gal }\end{array}$ \\
\hline \multirow[t]{5}{*}{ Potable: } & $A$ & 4.4 & 0.104 & 0.162 & 0.266 \\
\hline & B & 8.6 & 0.204 & 0.204 & 0.408 \\
\hline & c & 9.6 & 0.227 & 0.240 & 0.467 \\
\hline & D & 10.1 & 0.239 & 0.234 & 0.473 \\
\hline & $E$ & 1.7 & 0.040 & 0.061 & 0.101 \\
\hline \multirow[t]{5}{*}{ Pure: } & A & 4.4 & 0.104 & 0.162 & 0.266 \\
\hline & B & 8.6 & 0.204 & 0.204 & 0.408 \\
\hline & c & 17.6 & 0.416 & 0.352 & 0.768 \\
\hline & D & 10.1 & 0.239 & 0.234 & 0.473 \\
\hline & $E$ & 19.9 & 0.471 & 0.454 & 0.925 \\
\hline \multirow[t]{5}{*}{ High Purity: } & A & 13.4 & 0.371 & 0.441 & 0.758 \\
\hline & B & 17.7 & 0.419 & 0.461 & 0.880 \\
\hline & c & 17.6 & 0.416 & 0.588 & 1.004 \\
\hline & D & 21.1 & 0.499 & 0.630 & 1.129 \\
\hline & $E$ & 23.4 & 0.554 & 0.652 & 1.206 \\
\hline \multirow[t]{5}{*}{ U1tra Pure: } & A & 15.9 & 0.376 & 0.496 & 0.872 \\
\hline & B & 20.2 & 0.478 & 0.516 & 0.994 \\
\hline & $c$ & 20.1 & 0.476 & 0.643 & 1.119 \\
\hline & D & 23.6 & 0.559 & 0.704 & 1.263 \\
\hline & E & 23.4 & 0.554 & 0.700 & 1.254 \\
\hline
\end{tabular}

(a) Fixed charge rate $=17.4 \%$, Plant capacity factor $=80 \%$, Plant Life $=30$ years . 
TABLE A-2. Typical Raw Vlater Analyses.

Raw water type A:

Raw water type B:

Raw water type $\mathrm{C}$ :

Raw water type D:

Raw water type $E$ :

Total Hardness, mg/1

as $\mathrm{CaCO}_{3}$

Calcium hardness, $\mathrm{mg} / 1$ as $\mathrm{CaCO}_{3}$

Sodium, mg/1 as $\mathrm{CaCO}_{3}$

Alkalinity, $\mathrm{mg} / 1$ as $\mathrm{CaCO}_{3}$

Chloride, mg/l as $\mathrm{CaCO}_{3}$

Sulfate, $\mathrm{mg} / 1$ as $\mathrm{CaCO}_{3}$

Silica, mg/l as $\mathrm{CaCO}_{3}$

Iron, mg/1

Dissolved solids, $\mathrm{mg} / 1$
Surface, medium hardness, low dissolved and suspended solids, low silica.

Surface, medium hardness, low dissolved solids, high suspended solids, low silica.

We11 water, very hard, high dissolved solids, no suspended solids, high silica.

Surface water, hard, moderate dissolved solids, high suspended solids, some color, and silica.

We11 water, medium hardness, moderate dissolved solids, no suspended solids, some silica.

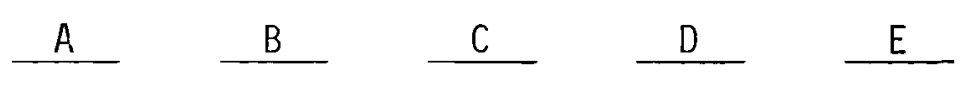

60

50

400

200

100

45

30

300

150

75

30

20

20

20

600

60

50

350

150

50

20

10

20

20

300

15

10

50

50

350

2

2

40

8

10

0.1

0.3

0.1

0.3

0.1

110

100

670

330

660 
TABLE A-3. Treatment Leve1s.

Potable Pure High Purity ultra Pure

$\begin{array}{lcccc}\mathrm{pH} & 6.0-9.0 & 6.5-7.5 & 6.5-7.5 & 6.5-7.5 \\ \begin{array}{l}\text { Hardness, } \\ \text { mg/liter }\end{array} & 50-150 & 20-40 & 2-4 & <0.05 \\ \text { as CaCO } \\ \begin{array}{l}\text { Dissolved } \\ \quad \text { Solids, } \\ \text { mg/liter }\end{array} & 100-250 & 50-100 & 5-10 & <0.05 \\ \begin{array}{l}\text { Iron, mg/liter } \\ \text { Silica }\end{array} & <0.3 & <0.1 & <0.1 & <0.01 \\ & 10-20 & 2 & <0.1 & <0.01\end{array}$

A-2. CHEMICAL, ELECTRICAL AND LABOR COSTS

A11 operating cost estimates are based on the following costs of water treatment chemicals, electricity and labor:

$\begin{array}{lll}\text { Lime } & - & \$ 0.017 / 1 \mathrm{~b} \\ \text { Soda Ash } & - & \$ 0.03 / 1 \mathrm{~b} \\ \text { Alum } & \$ 0.20 / 1 \mathrm{~b} \\ \text { Sulfuric Acid- } & \$ 0.37 / \mathrm{gal}\left(66^{\circ} \text { Baume) }\right. \\ \text { Labor } & \$ 10 / \text { wan-hour } \\ \text { Electricity }- & \$ 0.01 / \mathrm{KWH}\end{array}$


No. of

Copies

P. Leung

Bechtel Corporation

P.0. Box 60860

Terminal Annex

Los Angeles, CA 90060

G. R. Retti

Bechtel Corporation

P.0. Box 3965

San Francisco, CA 94119

J. P. Rossie

R. W. Beck and Associates

400 Prudential Plaza

Denver, C0 80202

B. Westre

Black Hills Power and Light Company

P.0. Box 1400

Rapid City, SD 57701

J. Sel1

Carolina Power \& Light Co.

336 Fayettesville Street

Raleigh, NC 27602

J. Morse

Catalytic Construction Corp.

P.0. Box 11402

Charlotte, NC 28029

H. H. Osborn

Combustion Engineering

Air Preheater Company

Wellsville, NY 14895

R. H. Holyoak

Commonwealth Edison

One First Plaza

P.0. Box 767

Chicago, IL 60690

C. L. Newman

Consolidated Edison Co. of New York, Inc.

4 Irving Place

New York, NY 10003
No. of

Copies

\author{
W. A. Messner \\ Consolidated Edison Co. \\ of New York, Inc. \\ 4 Irving Place \\ New York, NY 10003 \\ L. E. Wilkinson \\ Consultant \\ 6582 Ganon Street, S. E. \\ Salem, OR 97301
}

P. Sporn

Consultant Engineer

74 Trinity P1., Suite 511

New York, NY 10006

F. K. Moore

Cornel1 University

Ithaca, NY 14850

R. J. Haberski

Curtiss-Wright Corp.

One Passaic Street

Wood Ridge, NJ 07075

S. K. Blackley

Duke Power Company

P.0. Box 2178

Charlotte, NC 28201

J. K. Swindt

Ecodyne Cooling Products Co.

San Rosa, CA 95403

J. Maulbetsch

Electric Power Research Institute

3412 Hillview Avenue

P.0. Box 10412

Palo Alto, CA 94304

L. Geller

Empire State Electric Energy Research Corp.

1250 Broadway

New York, NY 10001 
BNWL - 2060

UC -12

\section{DISTRIBUTION}

No. of

Copies

\section{OFFSITE}

A. A. Churm

Chicago Patent Group

Energy Research and

Development Administration

9800 South Cass Avenue

Argonne, IL 60439

Office of Assistant General Counsel for Patents

Energy Research and Development Administration Washington, DC 20545

27 ERDA Technical Information Center

4 W. F. Savage

Advanced Concepts Evaluation

Branch - F-309

ERDA Division of Nuclear Research and Application Washington, DC 20545

T. Beresovski

Chief, Advanced Concepts Evaluation Branch

ERDA Division of Nuclear Research and Application Washington, DC 20545

D. C. Bauer

Director, Division of Nuclear Research and Application

Energy Research and Development Administration Washington, DC 20545

B. R. Dickey

Allied Chemical Company

550 2nd Street

Idaho Falls, ID 83401
No. of

Copies

J. S. Joyce

All is-Chalmers Power Systems, Inc.

1135 South 70th Street

West Allis, WI 53214

E. T. Wanderer

Aluminum Company of America

Alcoa Technical Center

Alcoa Center, $\mathrm{OH} 45069$

H. J. Janzon

American Electric Power

2 Broadway

New York, NY 10004

T. Woods

Arizona Public Service Co.

2121 W. Cheryl Drive

Phoenix, AZ 85021

M. W. Peterson

Babcock \& Wilcox

Fossil Power Division

20 South Van Buren

Barberton, $\mathrm{OH} 44203$

G. C. Creel

Baltimore Gas \& Electric Co. Gas \& Electric Building

Baltimore, MD 21203

E. Schinner

Baltimore Aircoil Co., Inc.

P.0. Box 7322

Baltimore, MD 21227

J. P. Budliger

Battelle-Geneva

7 Route De Drizi

1227 Geneva, SWITZERLAND 
No. of

Copies

F. H. Rainwater

Environmental Protection Agency

Pacific Northwest Water Laboratory

200 S.W. 35th Street

Corvallis, OR 97330

W. Hoydisch

Environmental Sciences and Services

44-43 37th Street

Long Island City, NY 11101

A. M. Rubin

Franklin Institute

Twentieth \& Parkway

Philadelphia, PA 19103

B. Davis

GEA Airexchangers, Inc.

46 Worthington Drive

Maryland Heights, MD 63043

A. C. Eulberg

General Atomic

P.0. Box 81608

San Diego, CA 92138

E. H. Miller

General Electric Co.

Large Steam Turbine Division

300 Nott Street

Schenectady, NY 12301

R. K. Shah

Harrison Radiator Division

General Motors Corp.

Lockport, NY 14094

J. F. Sebald

Gilbert Associates, Inc.

525 Lancaster Avenue

Reading, PA 19603

J. E. Taboric

Heat Transfer Research Inc.

1000 S. Fremont Avenue

Alhambra, CA 91802
No. of

Copies

E. C. Smith

Hudson Products

6855 Horwin Drive

Houston, TX 77036

M. W. Larinoff

Hudson Products

6855 Horwin Drive

Houston, TX 77036

C. Rocco

Italimpianti - Societa

Italiana Impianti p.a.

Piazza, Piccapietra 9

18121 Genoa, ITALY

J. L. Mulloy

Los Angeles Department of Water and Power

$111 \mathrm{~N}$. Hope Street

Los Angeles, CA 90012

R. J. Meyer

Louisiana Power \& Light Co.

142 Delaronde Street

New Orleans, LA 70174

R. Landon

Marley Co.

5800 Fox Ridge Drive

Mission, KS 66202

L. R. Glicksman

Massachusetts Institute of Technology

77 Massachusetts Avenue

Cambridge, MA 02139

R. Hofacher

Montana Power Co.

40 E. Broadway

Butte, MT 59701

W. G. Hoydysn

New York University

University Heights

New York, NY 10453 
No. of

Copies

W. Kals

Niagara Blower

405 Lexington Avenue

New York, NY 10017

R. H. Meyer

Northeast Utilities

P.0. Box 270

Hartford, CT 06101

L. P. Davis

Department of Mechanical Engineering

Oregon State University

Corvalitis, OR 97330

C. E. Wicks

Department of Chemical

Engineering

Oregon State University

Corvallis, OR 97330

J. W. Michel

OTEC Heat Exchange Project Activity

Oak Ridge National Laboratory

Box $Y$

Oak Ridge, TN 37830

F. F. Mautz

Pacific Gas \& Electric

77 Beale Street

San Francisco, CA 94106

P. G. Humphries

Pacific Power \& Light Co.

Public Service Bldg.

Portland, OR 97204

T. Rozenmann

PFR Engineering Systems, Inc.

Suite 832

4676 Admiralty Way

Marina del Rey, CA 90291

Prof. Ing. Carlo Roma

Piazza delle Muse 8

Rome, ITALY
No. of

Copies

A. C. Smith

Power Generation Cooling Sys tems

4714 - 52nd Street S.

Seattle, WA 98118

R. F. Walker

Public Service of Colorado

5900 E. 39th Avenue

Denver, CO 80207

E. D. Kist

Public Service of New Mexico Corporate Planning Dept.

Albuquerque, NM 87103

G. E. Collins

Research Cottrell

Hamon Cooling Tower Division

Box 750

Bound Brook, NJ 08805

R. Lindberg

Reynolds Aluminum Co.

Reynolds Metallurgical

Research Laboratory

Richmond, VA 23261

R. G. Lacy

San Diego Gas \& Electric

101 Ash Street

San Diego, CA 92107

R. L. Skone

Seattle City Light

1015 Third Ave.

Seattle, WA 98104

J. Rasband

Southern California Edison

2244 Walnut Grove Avenue

Rosemead, CA 91770

A.L. London

Department of Mechanical

Engineering

Stanford University

Stanford, CA 94305 
No. of

Copies

J. Y. Parce

Stearns and Rogers

$700 \mathrm{~S}$. Ash Street

Denver, CO 80222

D. H. Guild

Stone \& Webster Engineering

Corp.

225 Franklin Street

Boston, MA 02107

H. I. Wilson

Tampa Electric Co.

P.O. Box 111

Tampa, FL 33601

W. Keel

Texas Electric Service Co.

115 w. Seventh Street

Fort Worth, TX 76102

G. J. Kidd

Union Carbide Corp.

ORGDP - K-25

P.0. Box D

Oak Ridge, TN 37803

G. A. Englesson

United Engineers \&

Constructors

1401 Arch Street

Philadelphia, PA 19105

K. Simhan

University of Bremen

Bremen, WEST GERMANY

J. F. Kennedy

University of Iowa

Hydraulic Research Institute

Iowa City, IA 52240

J. H. Hutchinson

Utah Power \& Light

1407 W. N. Temple

Salt Lake City, UT 84103
No. of

Copies

S. Ragone

Virginia Electric \& Power Co.

700 E. Franklin Street

Richmond, VA 23261

G. H. Soule West Associates Sierra Pacific Power Co.

100 E. Moana Lane

Reno, NV 89510

J. A. Barnett

Executive Director

Western States Water Council

Room 1725

University Club Building

Salt Lake City, UT 84111

G. J. Silvestri

Westinghouse Electric Corp.

Steam Turbines Division

Lester Branch

Box 9175

Philadelphia, PA 19113

K. A. 0leson

Westinghouse Electric Corp.

Steam Turbines Division

Lester Branch

Box 9175

Philadelphia, PA 19113

ONSITE

2 ERDA Richland Operations Office, Program Division

P. G. Hol sted

W. A. Burns

Westinghouse Hanford Company Hanford Engineering Development Laboratory

J. Fletcher 
77 Battelle-Northwest

R. T. Alleman

P. A. Ard

J. W. Currie

D. E. Deonigi

J. G. Desteese

R. L. Dillon

D. W. Dragnich

R. L. Drake

D. W. Faletti

J. W. Finnigan

B. C. Fryer

C. H. Henager

A. B. Johinson

W. S. Kelly

R. S. Kemper

C. J. Knol1

W. V. Loscutoff

R. P. Marshall

D. E. Olesen

Y. Onishi

L. T. Pedersen

D. R. Pratt (10)

H. C. Riches

J. B. Schuette

G. C. Smith

J. S. Stoakes

A. M. Sutey

D. S. Trent

M. Vagins

R. A. Walter

R. L. Watts

R. D. Widrig

L. E. Wiles

File - B. M. Johnson (30)

Technical Information (3)

Technical Publications 